Historic, archived document

Do not assume content reflects current scientific knowledge, policies, or practices. 



\section{THE MOUNT DESERT NURSEREES} BAR HARBOR, MAINE

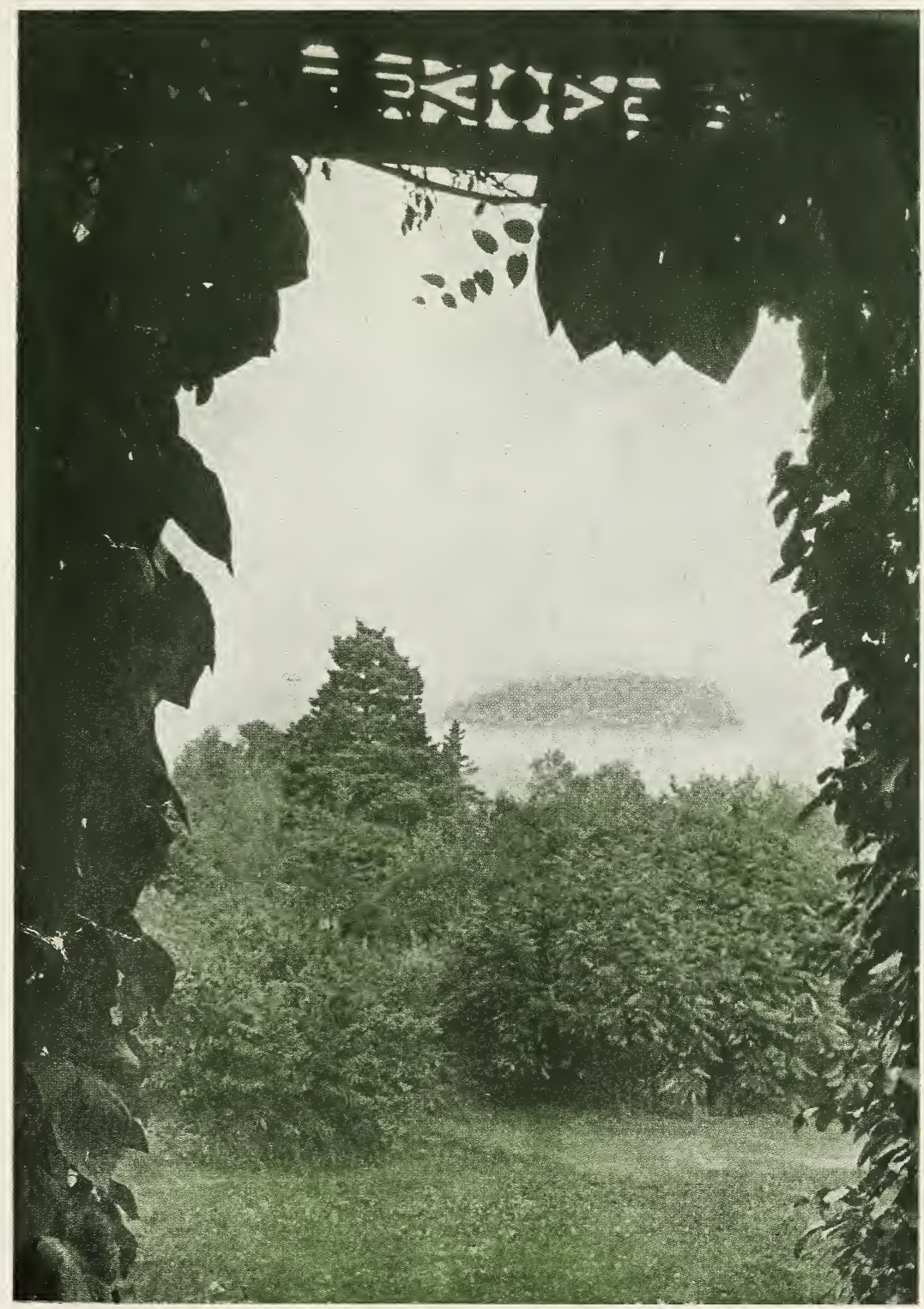




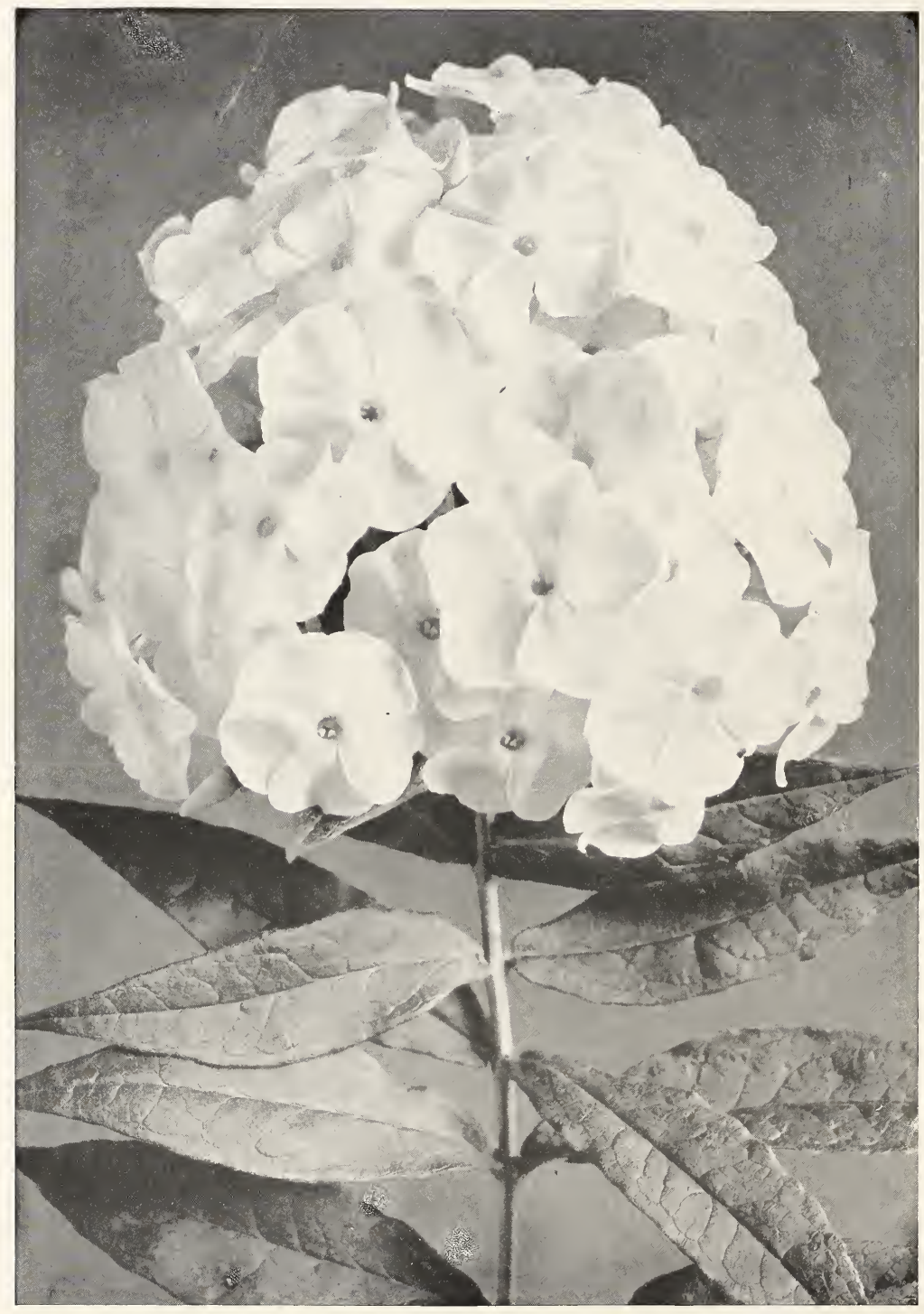

A SINGLE HEAD OF THE TALL, LATEBLOOMING PHLOX

These plants, well massed, are the best material the garden has for broad effects of color the whole season through

THE MOUNT DESERT NURSERIES, BAR HARBOR, MAINE 


\section{The Mount Desert Nurseries}

$\mathrm{T}$

HE Mount Desert Nurseries were founded twenty-eight years ago in recognition of the remarkable horticultural qualities Mount Desert Island had disclosed in its earliest pleasure garden, established fifteen years before and linked with the first development of summer residence upon the Island. This earliest garden was itself the outcome of century-old gardening on the Massachusetts shore, at Salem and in the vicinity of Boston, and the Mount Desert Nurseries were formed especially to grow, in a climate where they flourish remarkably, the old-fashioned flowers that had made those gardens, like the English, famous.

Mount Desert Island, lying where the northern flora meets a southern, and where the ocean, ebbing and flowing with a twelvefoot tide, tempers the climate winter and summer, is fitted uniquely for the growth of the hardy perennial plants, children of northern and of alpine regions. They grow in it with a vigor, and bloom with a brilliancy, rarely seen elsewheire, and the short northern summer leaves no period from spring to fall that is not rich in bloom.

The land the Nurseries occupy, the cultivated ground of one of the earliest farms in its region, is singularly favorable for a nursery purpose and beautiful in its setting, sheltered by mountains and bordering the Bar Harbor entrance to Lafayette National Park, on territory that once formed part of French Acadia.

The plants the Nurseries grow, woody and herbaceous, are those that the experience of over a quarter of a century has shown to be hardy and worth growing for their beauty's sake in pleasure grounds and gardens.

The herbaceous plants, plants which withdraw their life beneath the sheltering ground at the approach of winter, flourish in wide range upon the Island and may be sent out from it in exceptional health and vigor, strongly rooted.

The woody plants - trees and flowering shrubs - which the Nurseries grow are those that will flourish in a northern climate and whose form in each type is the selected best.

The Nurseries' gardens, carefully cultivated, are irrigated by a special system which ensures the maintenance of their plants in good lifting condition at all transplanting seasons, while the late northern spring enables lifting and transplanting to be carried on at a time when it is no longer possible in more southern sections. Plants so lifted may be replanted and not suffer where the season is advanced.

Lifting should be done, so far as possible, before new growth has started in the spring, or after the work of the foliage has ceased in fall, while root growth is still active.

A deep, moist soil, well drained and cultivated, and protection from excessive leaf evaporation until fresh roots are formed are what the newly transplanted plant requires. In planting, roots and rootlets should be spread out to come in contact widely with the soil, and the soil - well firmed after planting - should be good below them as around. The fine, feeding rootlets by which plants live, 
never exposed in nature, should never be exposed in lifting or replanting an instant longer than necessary but be kept continuously moist and covered.

The gardens of the Mount Desert Nurseries, showing a constant succession of bloom the season through, form at every period an exhibit interesting to garden lovers and useful to planters. Visitors are always welcome to them, while advice upon the different plants will be gladly given at the Nurseries' office, where papers illustrating and describing them may be obtained.

\section{ALPINE PLANTS.}

Rock Gardens, when properly constructed and artistically planted, form a most interesting and beautiful addition to estates or other gardens. The variety of plants suitable for growing among and over rocks is very large, and many of these, while beautiful in flower, are evergreen in character and have the great additional advantage of being able to withstand long periods of heat and drought: the Sedums, Sempervivums, and Saxifragas are notable examples. Nothing, again, could be more beautiful in spring than the Alpine Phloxes, which rapidly form wonderful carpets of bloom and clothe large surfaces of rock in the most charming manner, while their foliage is always bright and cheerful. Many early-flowering bulbs, too, can be used in the Rock Garden with delightful effect, and from the first touch of spring till late in the fall a wealth of bloom can be obtained.

Where space permits, shrubs in variety, also, lend themselves admirably to such planting. The trailing Junipers especially grow finely over dry and rocky situations and are native on our coast.

The eastern part of North America is climatically well adapted to Rock Gardening, and nothing is capable of giving pleasure greater than it to the garden lover and all who take an interest in garden plants. Suggestion of its possibilities may be obtained by visitors to the Nurseries from the Rock Garden, built to show them, near their office.

In our general list of Hardy Perennials those marked with a star (*) are especially adapted to Rock Garden planting.

\section{Hardy Herbaceous Perennials}

Our climate permits the growth only of the really hardy plants, but it gives them a vigorous constitution and a depth and brilliancy of color in their flowers that they take with them to new homes. Our list is the result of long trial, actual experiment, and careful selection. Assistance in the selection of the best varieties of plants, or advice as to the plants best adapted to special conditions of soil or climate, will be gladly given, personally or by letter.

\section{ACHILLEA. Yarrow.}

ptarmica plena. The Pearl. This variety has an abundance of pure white flowers on erect stems growing about two feet tall. It has an unusually long blooming period, commencing to flower in early July.

\section{ACONITUM. Monkshood.}

The Aconites are among the noblest of hardy garden plants, stately and grand in form and superb in color. Of easy cultivation, they do well planted in open sunny situations but will carry their bloom longer when planted in halfshade. The varieties listed below are all distinct and make a fine display during the summer and autumn months.

acutum. A handsome kind with rich violet flowers carried on stems five to six feet tall, with numerous side branches that help greatly in display. 35 cts. each; $\$ 3.00$ per $10 ; \$ 25$ per 100 . 
barbatum. A July flowering species, growing three to four feet tall; flowers bluish-violet with petals slightly darker-tipped.

35 cts. each; $\$ 3.00$ per $10 ; \$ 25$ per 100 .

cammarum Stoerkianum. This grows about five feet tall, commencing to flower in late July, its flowers being large and self-colored of a violet-purple.

35 cts. each; $\$ 3.00$ per $10 ; \$ 25$ per 100 .

exaltatum. A species, lighter in color of flower than the general, which grows from four to five feet tall and comes into flower in late July.

35 cts. each; $\$ 3.00$ per $10 ; \$ 25$ per 100 .

Fischeri. A late species, commencing to bloom with us in mid-September. It grows about three feet high with short spikes of large, pale blue flowers. Valuable for massing.

35 cts. each; $\$ 3.00$ per $10 ; \$ 25$ per 100 .

longigulatum. A species growing from three to four feet high which comes into bloom about the middle of August. The spikes are short, carrying compact bluish-violet flowers.

35 cts. each; $\$ 3.00$ per $10 ; \$ 25$ per 100 .

napellus. The oldest in cultivation and most widely known species, a native of Europe. It bears tall spikes of striking deep blue flowers, growing about five feet high.

35 cts. each; $\$ 3.00$ per $10 ; \$ 25$ per 100 .

napellus, var. albus. The nearest approach to a white Aconite; the flowers are lightly tipped with yellowish-green.

35 cts. each; $\$ 3.00$ per $10 ; \$ 25$ per 100 .

napellus, var. Meilchoferi. This is a fine dark blue form and is one of the first to flower, commencing the last of July and continuing through the greater part of August.

35 cts. each; $\$ 3.00$ per $10 ; \$ 25$ per 100 .

napellus, var. bicolor. A distinct and beautiful variety with clear-toned blue and white flowers, growing five to six feet tall. A very attractive form, commencing to flower about the first of August.

35 cts. each; $\$ 3.00$ per $10 ; \$ 25$ per 100 .

volubile tenuisectum. This is one of the newer varieties. It grows from three to four feet tall, with flowers of medium blue. 50 cts. each; $\$ 4.00$ per $10 ; \$ 30$ per 100 .

\section{*AJUGA. Bugle.}

genevensis. Purple flowers. Should have well-shaded position in rock garden. metallica crispa. Curious crinkled foliage on twisted stems.

*ALYSSUM. Madwort. Gold Dust.

One of the most valuable of yellow-flowering spring plants. saxatile compactum. Foliage velvety green. Flowers rich golden-yellow.

\section{ANCHUSA.}

The two varieties of this which we grow are among the most useful of garden plants, producing masses of flowers from July to September.

italica, var. Dropmore. Very deep Gentian blue, three to five feet. italica, var. Opal. Pale sky-blue, three to five feet.

\section{ANTHEMIS. Chamomile.}

Kelwayi. A good border plant with golden-yellow flowers.

\section{AQUILEGIA. Columbine.}

No plants surpass the Columbines in variety and range of color, in grace and charm. Flowering freely in the early summer, they are valuable alike in the garden and for cutting.

canadensis. A beautiful native plant, fine under cultivation; scarlet and yellow. chrysantha. Flowers a golden-yellow with long spurs; a tall species, growing three to four feet in height under good conditions.

coerulea. Fine, pale blue flowers with white centre; from the Rocky Mountains. Long-spurred Hybrids. From the mountain species, exhibiting wonderful shades and combinations of color.

All Hardy Perennials, unless otherwise noted, are 30 cts. each; $\$ 2.50$ per 10; $\$ 20.00$ per 100 . 
vulgaris. The native European Columbine which grows from two to three feet

high and has a sturdy habit, unlike the more delicately graceful American and Alpine species. It is an excellent border plant, grown in various colors and many garden forms.

vulgaris alba. A good white form of the above.

*ARABIS. Rock Cress.

alpina plena. Masses of double white flowers.

*ARENARIA. Sandwort.

caespitosa. A dwarf alpine plant with small, star-shaped flowers, admirable for producing a dense and verdant covering,

\section{*ARMERIA. Sea Pink.}

lauchiana alba. White flowers; three to six inches in height.

lauchiana rosea. Bright rose flowers.

lauchiana rubra. Deeper shade than rosea.

\section{ARTEMISIA. Wormwood.}

All the Artemisias, with the exception of lactiflora, are grown for their foliage only.

gnaphaloides. A beautiful plant, twelve to eighteen inches high, with fern-like foliage, nearly white.

pontica. Beautiful light-green foliage.

stelleriana. Finely cut and silvery foliage, attractive for its whiteness.

lactiflora. A recent introduction from China and one of the best late-blooming plants. It grows from four to five feet tall and has branching spikes of creamy-white flowers, pleasantly scented. It is a plant for which some good situation should be found in every garden.

35 cts. each; $\$ 3.00$ per $10 ; \$ 25$ per 100 .

\section{ASTILBE.}

For producing masses of flowers throughout the summer the Astilbes have been always widely cultivated but recently, by the introduction of new hybrids, their value has been greatly increased. Our collection is the most complete in this country.

ARENDSI. The following Arendsi varieties are among the most beautiful of hardy plants and should be grown in every garden. They grow about three feet tall and commence to bloom the last of July, continuing till September.

Ceres. A beautiful light rose, with branching spikes. 35 cts. each; $\$ 3.00$ per $10 ; \$ 25$ per 100 .

Gloria. One of the dwarfer forms, growing from two to two and one-half feet in height. A very attractive plant with rosy-carmine flowers.

35 cts. each; $\$ 3.00$ per $10 ; \$ 25$ per 100 .

Gruno. One of the most beautiful of the new hybrids with light and graceful spikes and salmon-colored heads.

35 cts. each; $\$ 3.00$ per $10 ; \$ 25$ per 100 .

Juno. Richly colored rosy-violet.

35 cts. each; $\$ 3.00$ per $10 ; \$ 25$ per 100 .

Marguerite. Distinct variety with rosy-lilac flowers.

35 cts. each; $\$ 3.00$ per $10 ; \$ 25$ per 100 .

Meta Immink. Graceful spikes of rose-colored flowers.

35 cts. each; $\$ 3.00$ per $10 ; \$ 25$ per 100 .

Moerheimi. Strong grower with heads of large white flowers.

35 cts. each; $\$ 3.00$ per $10 ; \$ 25$ per 100 .

Rose Perle. White petals fringed with a delicate silvery sheen.

35 cts. each; $\$ 3.00$ per $10 ; \$ 25$ per 100 .

Salland. The tallest of the Arendsi varieties, coming into flower somewhat earlier than the others. A distinct form and very effective, with deep red flowers.

35 cts. each; $\$ 3.00$ per $10 ; \$ 25$ per 100 .

Venus. Deep, fine rose with tall, branching spikes.

35 cts. each; $\$ 3.00$ per $10 ; \$ 25$ per 100 .

Vesta. Light rose. A most attractive variety.

35 cts. each; $\$ 3.00$ per $10 ; \$ 25$ per 100 .

All Hardy Perennials, unless otherwise noted, are 30 cts. each; $\$ 2.50$ per $10 ; \$ 20.00$ per 100 . 
White Pearl. Fine white variety with distinct foliage and large flower heads. 35 cts. each; $\$ 3.00$ per $10 ; \$ 25$ per 100 .

Davidii. A very striking species of recent introduction with bold foliage and numerous branching spikes of reddish-violet flowers.

35 cts. each; $\$ 3.00$ per $10 ; \$ 25$ per 100 .

Hybrid Peach Blossom. A compact plant growing about two feet tall with numerous spikes of pretty pink flowers.

35 cts. each; $\$ 3.00$ per $10 ; \$ 25$ per 100 .

Hybrid Queen Alexandra. Deep pink flowers on stems three feet tall. 35 cts. each; $\$ 3.00$ per $10 ; \$ 25$ per 100 .

\section{ASTER. Michaelmas Daisy.}

The Autumn Asters, natives of the New England states, are among the most beautiful of late-flowering plants, worthy in their season of a garden by themselves. They are of wide variety in habit, form and color; the ones we list are fine.

Novae Angliae. Bright purple flowers, four feet.

Novae Angliae rosea. Bright pink flowers, four feet.

Novae belgica Cleopatra. Light heliotrope, five feet.

Novae belgica Climax. Light lavender-blue, five feet.

Novae belgica White Climax. Splendid form of the above.

Novae belgica St. Egwin. Soft rosy-pink; three to four feet.

\section{*AUBRETIA. Purple Rock Cress.}

hybrids. These are dwarf plants producing masses of richly colored bloom and carpeting the ground.

\section{BAPTISIA.}

australis. A handsome plant with fine foliage and deep blue, lupin-like flowers in long racemes.

\section{BOCCONIA. Plume Poppy.}

cordata. A tall, strong-growing plant with large heart-shaped leaves and spikes of purplish-white flowers, very striking in wild garden planting and the shrubbery.

\section{BOLTONIA.}

asteroides. White, aster-like flowers, coming in September; four to six feet tall. A useful border plant, rapidly forming strong clumps.

latisquama. Flowers pink, shaded to lavender; four to five feet tall, blooming in September and October.

\section{BUDDLEIA.}

A very desirable Chinese plant producing lilac-like flowers in long racemes throughout the summer, fine in the garden border and valuable for cutting.

variabilis magnifica. One of the best varieties, with violet-lavender flowers on long stems.

\section{CAMPANULA. Bellflower.}

The Campanulas are all fine garden or border plants. The Alpine species are delightful in the rock garden, increasing quickly and producing a wealth of blossoms.

*carpatica. Large, pale blue flowers.

* carpatica alba. A pure white flowering form.

* glomerata acaulis. An attractive species growing about nine inches high and producing an abundance of dark blue or purple flowers.

*glomerata Dahurica. One of the best, producing large masses of clustered purple flowers on stems from twelve to eighteen inches high.

latifolia alba. A strong-growing variety with handsome pure white flowers on stems about four feet tall.

latifolia macrantha. Differing from the above only in the color of its flowers, which are a rich blue. Both varieties commence to flower about July first.

medium. Canterbury Bells. Famous old garden flowers, producing, planted in masses, wonderful effects of color. They are biennial and the ones offered are grown for flowering the same season. Separate colors; pink, blue and white. 35 cts. each; $\$ 3.00$ per 10 ; $\$ 25$ per 100 .

All Hardy Perennials, unless otherwise noted, are $30 \mathrm{cts}$. each; $\$ 2.50$ per $10 ; \$ 20.00$ per 100 . 
persicifolia grandiflora. Peach-leaved Bellflower. A beautiful plant, with spikes of large, single, blue flowers borne through July and the early part of August.

persicifolia grandiflora alba. A pure white form of the above.

persicifolia Moerheimi. One of the finest, with large double white flowers.

rapunculoides. A strong-growing, vigorous plant, growing two to three feet high and readily naturalized.

*rotundifolia. Harebell. A light and graceful plant with nodding, deep blue flowers. Stems about nine inches long; flowers from spring to fall.

\section{*CERASTIUM.}

tomentosum. Silvery foliage, and sheets of pure white flowers in June and July.

\section{CHELONE.}

North American plants nearly allied to the Pentstemons.

Lyoni. Forms a dense mass of stems with deep green foliage from which rise red, clustered flowers in the late season.

\section{CHRYSANTHEMUM. Daisy.}

maximum King Edward. A very fine daisy with deep green foliage and immense, pure white flowers on stems two feet high. Blossoms in June and July and is splendid for cutting.

uliginosum. A strong-growing plant, bearing in the late season white, daisylike flowers in great profusion.

\section{CIMICIFUGA.}

The Cimicifugas, with graceful, wand-like spikes of bloom, are very attractive in the late summer and early autumn.

cordifolia. This is the earliest of the group to bloom, commencing to flower about August 25th. Tall stems of white flowers.

japonica. This species, growing about two and one-half feet high, is covered with pretty, star-like flowers, blooming in early September.

simplex. Very handsome foliage and pendulous spikes of pure white flowers which are produced freely.

\section{CLEMATIS.}

integrifolia caerulea. An herbaceous species, growing about two feet tall, with clear blue flowers.

CONVALLARIA. Lily-of-the-Valley.

An old-time favorite, delightful for naturalizing in shady spots.

75 cts. per 10 Pips.

35 cts. per clump; $\$ 3.00$ per 10.

\section{DELPHINIUM. Larkspur.}

No plants excel the tall-growing perennial Larkspurs in stately beauty. Whether massed in the mixed border or grouped apart they produce a grand effect. The named varieties listed below are anong the best.

Belladonna. A very popular variety, growing about three feet tall, with branching stems producing quantities of pale blue flowers in summer; more sparingly till fall.

Belladonna, var. Cliveden Beauty. A fine variety, clear in color and flowering in great abundance.

formosum. Similar in habit to Belladonna but having rich dark blue flowers. formosum coelestinum. A beautiful sky-blue variety.

hybrids, mixed. These plants are grown from seed saved from the best English named varieties, and embrace a wide variety of shade and color.

Lamartine. One of the best of the new varieties, with very dark blue flowers; of medium height.

DIANTHUS. Pink.

A genus of the highest garden value, containing several of our finest forms of hardy flowers - the Carnation, Pink, and Sweet William - besides numerous alpine and rock plants that are among the most charming of such type. The species all succeed best in light, good soil and a well-drained, sunny position.

All Hardy Perennials, unless otherwise noted, are $30 \mathrm{cts}$. each; \$2.50 per 10;\$20.00 per 100 . 
barbatus. An old-time garden favorite and one of the best of hardy flowers blooming in early summer. The flowers are borne in dense, flat heads, or corymbs, and are wonderfully rich in color, ranging from glowing crimson-red to white; or particolored. The best effect is obtained by planting in separate colors, for which the new shades of pink and scarlet are in great demand. We supply only strong, field-grown plants.

*caesius. One of the prettiest of the dwarf pinks with rosy, fragrant flowers, valuable for the rock garden.

*deltoides. A native English plant with pale pink flowers on stems from six to twelve inches long, blooming in July and August.

*plumarius. The parent of numerous varieties of garden pinks, grown best on banks above the level ground or in the rockery. The type grows about a foot in height, blooming in July and August.

\section{DICENTRA.}

Attractive plants belonging to the Fumitory order.

*eximia. A long-blooming rock or border plant, with numerous racemes of pendulous pink blossoms. Foot to eighteen inches.

spectabilis. Bleeding Heart. A fine old border plant from China, where it has been grown from time immemorial in the Mandarin gardens. It bears pendent, heart-shaped flowers, rosy-pink and white, in strings on slender stems. Unique in type and of a rare, quaint grace, it is one of the bestloved and most familiar plants of old-time gardens.

\section{DICTAMNUS.}

Fraxinella. A fine old garden plant growing about two feet tall and forming in the early summer dense tufts above which rise racemes of red and white flowers. Does best in light soil.

\section{DIGITALIS. Foxgloves.}

purpurea. No plants are finer for grouping than those of the European Foxglove, D. purpurea. Grown in the partial shade of trees against a woody background, they produce a superb effect. The flowers are borne in long racemes, rising above the foliage, successively opening from the bottom up and draping the stem with pale purple and white bells.

\section{DORONICUM. Leopard's Bane.}

plantagineum excelsum. A plant of the Daisy type, bearing in late spring and early summer great quantity of bright and clear-toned yellow flowers. Excellent for cutting.

\section{ECHINOPS. Globe Thistle.}

ritro. A plant from the Mediterranean region, growing from three to four feet high and flowering in July and August. Its flowers are blue, clustered in large globular heads. A striking border plant.

\section{*ERYNGIUM. Sea Holly.}

planum. Whether in the garden border or rock garden few plants excite greater interest than this. Thistle-like in type though belonging to the Parsley family, the stems, singularly beautiful with vivid steel-blue tints, are surmounted with an involucre still more brilliant.

\section{*ERYSIMUM.}

rupestre. A good rock-garden plant growing six to eight inches high and blooming with clear yellow flowers in May.

\section{EUPATORIUM.}

ageratoides. Useful border plant from three to three and one-half feet tall with clustered heads of white flowers. August and September.

\section{*EUPHORBIA. Spurge.}

epithymoides. A showy, useful plant about eighteen inches tall. Covered with yellow flowers in early summer.

\section{FUNKIA. Plantain Lily.}

Japanese plants of the Lily order with broad green leaves and flower stems terminating in racemes of pure white or pale mauve flowers.

lancifolia alba marginata. A variety of one of the smaller species with leaves beautifully lined with white along the margin; grown principally for foliage effect and fine for edging.

All Hardy Perennials, unless otherwise noted, are 30 cts. each; $\$ 2.50$ per $10 ; \$ 20.00$ per 100 . 
Sieboldiana. A vigorous plant with splendid foliage; admirable for grouping. sub-cordata grandiflora. The finest of all in flower, producing in August and September numerous spikes of pure white, sweet-scented flowers rising above a bed of pale green foliage.

undulata. Green and white variegated foliage, with mauve flowers. Fine for edging.

viridis. A garden form with narrow leaves.

\section{*GALIUM.}

mollugo. A good plant for the border or the rockery. It grows from one to three feet tall and bears a profusion of tiny, white clustered flowers.

verum. Lady's Bedstraw. A plant of low, spreading habit bearing innumerable tiny yellow, strongly fragrant flowers in panicles and having feathery foliage. It naturalizes readily under good conditions. Used in old days in Ladies' bowers for fragrant bedding.

\section{*GERANIUM.}

The hardy Geraniums in their finer species are plants excellently fitted for the rock garden or the garden border.

armenum. Rich crimson flowers on stems eighteen inches high. June and July. grandiflora. Very large, showy, blue flowers; eighteen inches. June and July. platypetalum. Large, rosy-purple flowers; eighteen inches. June and July. pratense. Two feet tall, with blue flowers.

pratense album. White form of the above.

sanguineum album. Serrated foliage; flowers pure white.

\section{$*$ GEUM.}

Whether singly or massed, the Geums, with pale green foliage and richly colored flowers whose form resembles that of the strawberry flower, are attractive plants, excellent in the rock garden.

Heldreichi splendens. Glowing orange-scarlet flowers.

\section{GYPSOPHILA.}

The Gypsophilas, in their garden species, are plants of light and airy grace bearing myriads of tiny flowers in slender, spreading panicles. The strongergrowing, border species are invaluable for cut-flower purposes, associating well with other flowers, and are widely grown for this as well as for grace and beauty in the garden.

acutifolia. A tall species with narrow leaves and small white flowers.

* cerastoides. A fine species for the rock garden, growing about three inches high and producing in profusion in June and July small, white flowers marked with pink.

*repens. A fine trailing plant for the rockery, bearing clouds of tiny white flowers in July and August.

paniculata. Baby's Breath. A strong-growing plant with tiny flowers borne in profusion on much-branching, spray-like stems. A good border plant; also widely grown for cutting, to use decoratively with other flowers.

paniculata fl. pl. New double variety of great beauty. One of the most attractive plants in cultivation. We have only a few to offer, and only as they are selected when in bloom.

Our price, each 75 cts.

\section{HELENIUM.}

The Heleniums are vigorous North American composites, flowering in profusion a1 the season's end and thriving readily in good garden soil. Their rich, golden-yellow flowers are borne in massive heads and they are of high importance for giving color to the garden or the hardy border at the season's end.

autumnale pumilum magnificum. A variety growing three feet high and widely branching, with heads of golden-yellow flowers.

autumnale rubrum. A plant of robust growth, three to four feet high, bearing bright reddish-yellow flowers in August and September.

autumnale superbum. Large heads of golden-yellow flowers on six-foot stems. Of great value for producing masses of golden color in the late season.

Riverton Beauty. Rich lemon-yellow, with large purplish-black cone, blooming in August and September. Four feet.

All Hardy Perennials, unless otherwise noted, are $30 \mathrm{cts}$. each; $\$ 2.50$ per $10 ; \$ 20.00$ per 100 . 


\section{*HELIANTHEMUM. Rock Rose.}

Beautiful evergreen plants which form broad, low clumps and produce masses of flowers from July to September. Excellent both for rock and border planting.

chamaecistus. This is the commonly cultivated variety, running into many forms.

Salmon Queen. A hybrid form with salmon-pink flowers.

\section{HELIANTHUS. Sunflower.}

The Sunflowers are vigorous North American composites whose finer species are valuable in the hardy border for late summer and autumn color, producing masses of golden flowers.

rigidus Miss Mellish. Large, semi-double flowers on stems four to five feet tall. A showy and effective plant.

strumosa. Large, clear yellow flowers on five-foot stems.

HEMEROCALLIS. Day Lily.

The Day Lilies form one of the most valuable groups of hardy garden plants, and are splendid also for naturalizing. They form broad clumps of grass-like foliage, sending up in June numerous stems of lily-shaped yellow flowers, blooming afresh in long succession.

aurantiaca. Large orange flowers on tall stems.

citrina hybrids. Beautiful lemon-colored flowers, borne on tall slender stems four to five feet tall and blooming with us until September.

35 cts. each; $\$ 3.00$ per $10 ; \$ 25$ per 100 .

Dumortieri. One of the earliest to flower; flowers of a rich yellow on stems two and one-half feet tall.

flava. Clear yellow flowers on three-foot stems. One of the earliest to bloom, coming into flower in June.

hybrida Gold Dust. Of dwarf habit, with golden-yellow flowers.

hybrida luteola pallens. Clear yellow flowers, borne on three-foot stems. July and August.

50 cts. each; $\$ 4.00$ per $10 ; \$ 35$ per 100.

hybrida Orange Man. Large orange-yellow flowers on three-foot stems. Midsummer flowering.

hybrida Sovereign. Soft chrome-yellow flowers, shaded brown on the outside, blooming in late June. Two and one-half feet.

Middendorfii. Fragrant, orange-yellow flowers, blooming in May and June. About one and one-half feet.

Thunbergi. Pale yellow flowers, similar to flava but later flowering.

\section{HESPERIS.}

matronalis. Dame's Rocket. A popular old garden plant and one of the most desirable of hardy flowers, fragrant and rosy-purple, borne in tall, conspicuous spikes. June and July. Used in early English days for strewing floors of ladies' apartments.

matronalis alba. Showy terminal spikes of white flowers.

\section{*HEUCHERA.}

North American plants of the Saxifrage order, of striking grace and beauty. They bear loose spikes of flowers during July and August, and are excellent for the garden or the rockery. They grow, according to the species, from one to two feet high.

brizoides. A beautiful plant with many spikes of pink flowers.

brizoides gracillima. One of the best.

sanguinea. Numerous spikes bearing small but brilliant coral-red bells. It is a true alpine, growing wild among the cliffs of the Mexican Mountains.

\section{HOLLYHOCKS.}

We grow a collection of the best of the double varieties of these in separate colors and supply only strong plants for spring delivery.

\section{*IBERIS. Candytuft.}

The Candytufts are among the most charming of alpine plants, flowering in spring and early summer and invaluable in the rock garden or the early border.

sempervirens. Dark, glossy, evergreen foliage, with numerous heads of the purest white flowers.

All Hardy Perennials, unless otherwise noted, are $30 \mathrm{cts}$. each; $\$ 2.50$ per $10 ; \$ 20.00$ per 100 . 
The Incarvilleas are among the most distinct plants of recent introduction, and among the most handsome, their large, trumpet-shaped flowers resembling those of the Bignonia.

Delavayi. Large, glossy foliage. Stems two feet high. Trumpet-shaped flowers, rosy-carmine in color, with handsome throat.

\section{IRIS.}

The Irises rank high among the garden flowers, excelled by none in beauty or variety. They flower in the early season, from spring to midsummer, storing up afterward in bulb or rhizome material for the coming year.

\section{IRIS GERMANICA.}

The garden hybrids known under the general name of German Iris are derived from various spring-flowering species native over Europe. They have great beauty, wide variety in form and color, and some are strongly fragrant. They like a well-drained sunny situation, and are of easy cultivation.

In the following description, 's' signifies standard or upright petal; 'f,' flag or drooping petal.

Aika. s, pure white; f, white with faint violet markings; flowers of medium size.

Caprice. s and f, rosy-violet, the falls of deeper shade; flowers of good size. A fine variety.

Fro. s, deep yellow; f, a rich mahogany color.

Idion. s, bright yellow; f, yellow heavily overlaid with reddish-brown. Flowers medium to large.

Ignacita. s, pale lavender; f, lavender and rosy-lilac. Flowers large.

Jaune paille. s, straw-colored yellow; f, cream-white, reticulated brown.

Lord Seymour. Both $\mathrm{s}$ and $\mathrm{f}$ white, tinged and marginated with azure blue, resembling the well-known variety Mme. Chereau but of stronger growth.

Lorelli. s, yellow, marked with rosy-scarlet; f, rosy-purple, reticulated white and edged with yellow.

Minerva. $s$ and $f$, in general effect, a deep rosy-violet.

Perfection. s, deep lavender; f, rich velvety purple.

Princess Victoria Louise. s, pale yellow; f, rosy-violet. A fine variety.

Rebecca. s, chrome-yellow; f, rich violet.

Rhein Nixe. s, pure white; f, violet. A fine combination of color and one of the best German Irises.

Rose de Chine. $\mathrm{s}$ and $\mathrm{f}$, a beautiful lavender with pinkish shade, rare among the German Irises.

Squalens “Arnold." s, a bronzy-lavender; f, deep velvety purple, slightly reticulated with white.

Asiatica. s, deep lobelia blue, veined dark violet and tinted yellow at the base; f, violet-purple, shaded to violet. A grand form.

Bergiana. s, lavender; $f$, a deeper shade.

Gracchus. s, reddish-brown, reticulated white; f, pure yellow.

Jenny Lind. s, buff yellow; f, deep purple, slightly veined yellow. A fine plant.

Mme. Chereau. White and lavender, veined along the edges with yellow stamens. Tall; three feet. One of the best.

Mrs. H. Darwin. Almost white.

\section{IRIS PALLIDA.}

These belong to the great group of German Irises but form a well-defined sub-group within it, distinct, beautiful and stately. When in full bloom, the flowering spikes reach four feet in height, bearing a succession of large, pale mauve or deeper purple flowers, strongly fragrant.

dalmatica. Beautiful pale blue and white flowers on stems growing from three to four feet in height.

Khedive. A tall, free-flowering form with rich lavender-blue flowers.

racemosa. A richly colored form of the preceding.

speciosa. A fine variety, with effect of rosy-purple color.

Tinea. A magnificent flower; lavender-blue with pale violet shadings.

All Hardy Perennials, unless otherwise noted, are 30 cts. each; $\$ 2.50$ per 10; $\$ 20.00$ per 100 . 


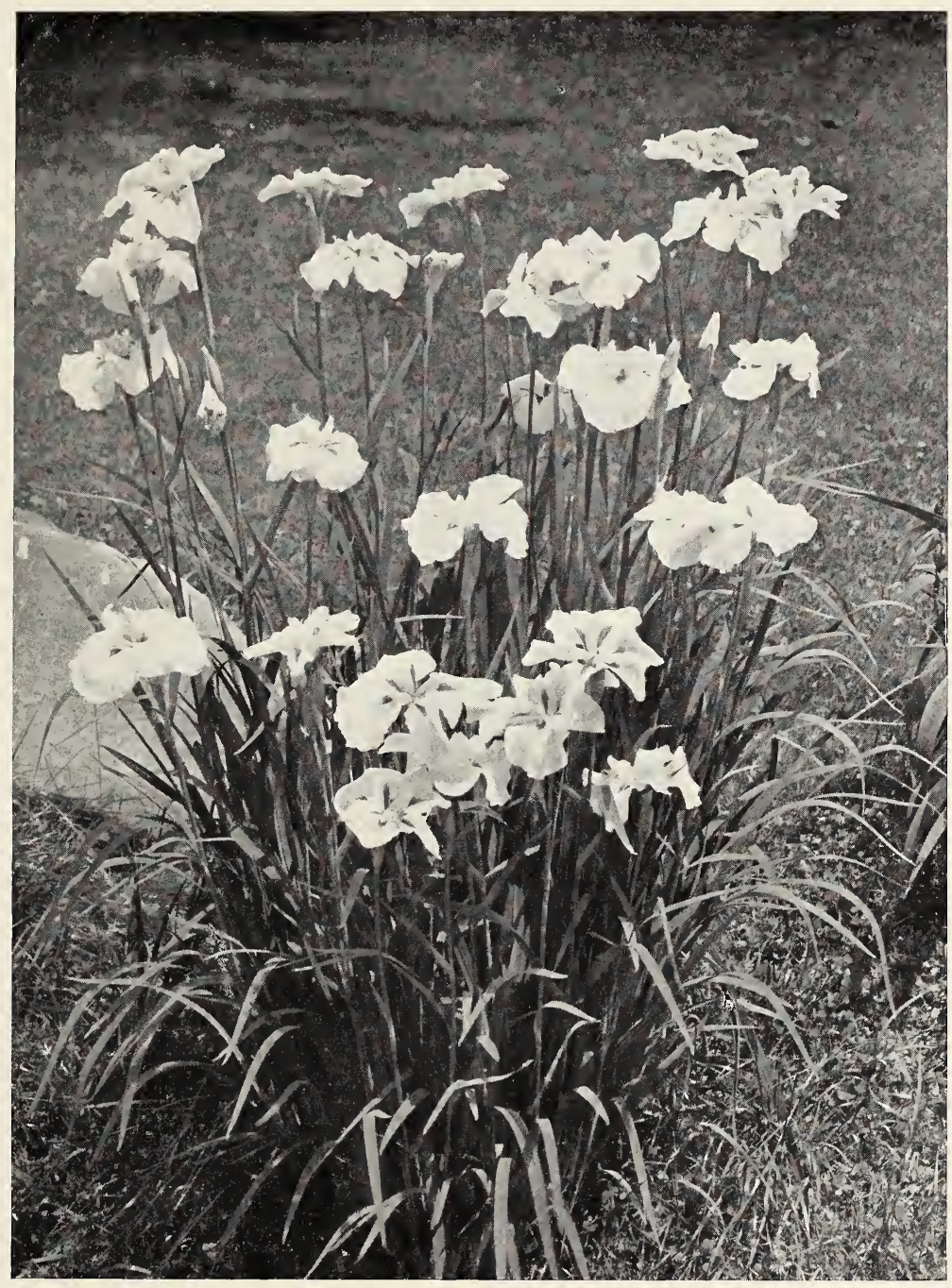

JAPANESE IRIS

Growing in the grass beside a stream

THE MOUNT DESERT NURSERIES, BAR HARBOR, MAINE 



\section{IRIS PSEUDACORUS.}

A tall waterside and marshland plant with rich yellow flowers and swordlike leaves, splendid for naturalizing.

\section{IRIS PUMILA.}

Dwarf Irises from the Levant, parents of many lovely garden varieties. The flowers are large, deep violet or straw-colored in the type; they bloom in spring, the first among the garden Irises.

\section{IRIS SIBIRICA.}

The Siberian Iris is a vigorous plant with grass-like foliage and flower stems two to three feet high, bearing in profusion small but showy blue-purple flowers, delicately veined with white. Planted in the garden border it forms quickly splendid clumps, and is grand by the waterside.

sibirica alba. A pure white flowering counterpart.

sibirica maxima. A strong-growing form.

sibirica orientalis. A distinct and fine variety, less tall than the type but with broader falls and of a richer blue.

sibirica orientalis, var. Snow Queen. One of the best, with conspicuous white flowers borne in profusion.

IRIS KAEMPFERI. Japanese Iris.

The Japanese Irises form a distinct group, flowering after the German and Dalmatian groups have ceased. The Japanese make their coming into bloom the occasion of one of their most famous floral festivals. Unlike the Irises of the Germanica type, they are moisture-loving plants, growing natively in meadow-lands and marshes, and during their growing season should be well supplied with water. The flowers are of great breadth of petal and wonderful, wide-ranging color, poised on their stems like gigantic, tropical butterflies.

\section{Single Varieties.}

Helen von Sieboldt. Deep pink; white lines.

$$
35 \text { cts. each; } \$ 3.00 \text { per } 10 ; \$ 25 \text { per } 100 \text {. }
$$

Painted Lady. White, richly suffused and striped with bright pink; very showy. 35 cts. each; $\$ 3.00$ per $10 ; \$ 25$ per 100 .

Venus. Pure white. A strong grower and free bloomer. 35 cts. each; $\$ 3.00$ per $10 ; \$ 25$ per 100 .

Alba plena. White and very large.

\section{Double Varieties.}

35 cts. each; $\$ 3.00$ per $10 ; \$ 25$ per 100.

Blue Danube. Pure rich blue, yellow centre.

35 cts. each; $\$ 3.00$ per $10 ; \$ 25$ per 100.

Commodore Perry. Dark violet-red; medium size.

35 cts. each; $\$ 3.00$ per $10 ; \$ 25$ per 100 .

\section{IRIS MONNIERI.}

A noble Flag, growing three to four feet in height with fragrant, goldenyellow flowers, borne at the level of the leaves. Flowers in early July.

LAVANDULA. Lavender.

vera. An old garden favorite, shrub-like in character, with fragrant blue flowers blossoming in July.

\section{LIATRIS. Blazing Star.}

callilepsis. An atractive plant growing about two and one-half feet tall and bearing an abundance of rich purple flowers in July and August.

pycnostachya. A species bearing long dense spikes of rosy-purple flowers late in summer, remaining long in bloom.

\section{LILIUM. Lily.}

The Lilies are among the oldest of garden plants, and there are none more beautiful. The many kinds in cultivation afford rich choice, alike in type and season.

auratum. The golden-rayed lily of Japan. A grand species with magnificent white flowers with crimson spots and broad golden bands. August. 50 cts. each; $\$ 4.50$ per $10 ; \$ 30$ per 100 .

candidum. Madonna Lily. Pure white. July. 40 cts. each; $\$ 3.50$ per $10 ; \$ 30$ per 100.

All Hardy Perennials, unless otherwise noted, are $30 \mathrm{cts}$. each; $\$ 2.50$ per 10; $\$ 20.00$ per 100 . 
Henryi. A Chinese lily of the Speciosum type with deep-colored, lemon-yellow flowers, marked with brown spots.

$$
75 \text { cts. each; } \$ 6.00 \text { per } 10 \text {. }
$$

regale. Syn. myriophyllum. A magnificent lily of recent introduction which has proved absolutely hardy. Its flowers are white slightly tinged with pink, with a beautiful shade of canary-yellow at the centre. It is delightfully fragrant.

$$
\$ 1.00 \text { each; } \$ 8.00 \text { per } 10 \text {. }
$$

speciosum album. A pure white, fragrant lily, blooming late. One of the finest of a splendid group.

$$
50 \text { cts. each; } \$ 4.50 \text { per } 10 ; \$ 40 \text { per } 100 .
$$

speciosum magnificum. Extra large flowers, white deeply overlaid with red. August and September.

$$
50 \text { cts. each; } \$ 4.50 \text { per } 10 ; \$ 40 \text { per } 100 .
$$

speciosum rubrum. White, spotted and ribbed with red. August and September. 50 cts. each; $\$ 4.50$ per $10 ; \$ 40$ per 100 .

superbum. A stately native lily of the Turk's Cap type, growing from seven to eight feet tall and terminating in great spikes of orange-colored flowers. July and August.

$$
30 \text { cts. each; } \$ 2.50 \text { per } 10 ; \$ 20 \text { per } 100 \text {. }
$$

tigrinum splendens. Tiger Lily. A well-known species of vigorous habit with thickly spotted, orange-red flowers, blooming at the season's end. 30 cts. each; $\$ 2.50$ per $10 ; \$ 20$ per 100 .

\section{*LINARIA.}

pallida alba. A dense, creeping, vine-like plant with small white flowers. Valuable for planting along the edge of rocks or covering vacant space in the rock garden.

\section{*LINUM. Flax.}

perenne. A useful, blue-flowered plant for border or rockery, growing about eighteen inches tall and blooming throughout the summer.

\section{LOBELIA.}

cardinalis. Cardinal Flower. One of the grandest of herbaceous plants for a moist situation, where it will grow fully four feet tall, bearing spikes of deep, rich scarlet flowers.

cardinalis alba. A white form of the above. Stock limited. 35 cts. each; $\$ 3.00$ per $10 ; \$ 25$ per 100 .

\section{LYTHRUM. Purple Loosestrife.}

roseum superbum. A fine garden variety of an English meadow plant which bears long spikes of rosy-purple flowers and is admirable for grouping by the waterside or in moist places, where it produces a grand effect.

\section{MONARDA.}

didyma. Oswego Tea or Bee Balm. An aromatic North American herb with red flowers, blooming through the summer.

didyma Cambridge Scarlet. A fine form with bright scarlet flowers. Excellent for grouping.

salmonea. One of the best of recent introductions. Salmon-pink flowers; July and August.

\section{MONTBRETIAS.}

A magnificent class of bulbs, producing bloom in fine, continuous display from July to October. Splendid for cutting and of easy culture.

Ernest Davison. Rich orange suffused with carmine.

\section{5 cts. each; $\$ 1.25$ per $10 ; \$ 10$ per 100 .}

George Davison. Beautiful orange-yellow. Long stems, with flowers large and well open.

15 cts. each; $\$ 1.25$ per $10 ; \$ 10$ per 100 .

King Edmund. Strong, branching spikes of golden-yellow flowers.

15 cts. each; $\$ 1.25$ per $10 ; \$ 10$ per 100.

Westwick. Beautiful golden-yellow.

15 cts. each; $\$ 1.25$ per $10 ; \$ 10$ per 100 .

\section{MYOSOTIS. Forget-me-not.}

palustris, var. semperflorens. An alpine plant with heavenly blue flowers in vast profusion. Delightful for naturalizing in moist places or along the side of streams.

All Hardy Perennials, unless otherwise noted, are 30 cts. each; $\$ 2.50$ per $10 ; \$ 20.00$ per 100 . 
glechoma. Ground Ivy. Excellent for ground cover in a shaded position, or in the rockery.

Mussini. Grown for foliage effect. Leaves green above and whitish underneath; branches ascending.

\section{OENOTHERA. Evening Primrose.}

The Evening Primroses are among the most delightful of hardy plants, putting forth a constant succession of fresh flowers from early summer on and admirable for sunny positions in the garden border or the rockery.

Frazeri. An erect perennial growing two to three feet high with yellow, clustered flowers, borne in great profusion.

fruticosa major. A fine, strong-growing and free-flowering plant, with showy yellow blossoms.

* Missouriensis. A prostrate form bearing large and widely opening yellow flowers, often five inches in diameter, which it produces freely in succession through the summer.

Youngi. A species growing about two feet high which has long, pendulous branches covered with bright yellow flowers.

\section{PACHYSANDRA.}

terminalis. A trailing plant forming broad mats of bright green, glossy foliage. Invaluable as a cover plant, whether in shade or sun. Pot-grown plants; 25 cts. each; $\$ 2.00$ per $10 ; \$ 15$ per 100 .

\section{PAPAVER. Poppy.}

orientale. Oriental Poppy. A robust perennial which makes a gorgeous display in the early summer and is among the best of garden plants, stately in habit and superb in color.

orientale, var. Princess Victoria Louise. One of the best of the bright scarlet varieties.

orientale, var. Queen Alexandra. A beautiful clear rose.

nudicaule. Iceland Poppy. A beautiful northern plant that blooms abundantly in spring and less abundantly throughout the summer. We supply them in selected colors, white, yellow, and orange.

20 cts. each; $\$ 1.50$ per $10 ; \$ 12$ per 100 .

\section{PENTSTEMON.}

barbatus Torreyi. An erect plant, sending up long, slender spikes of bright coral-red, honeysuckle-like flowers, beloved by the bees. July and August. From the Rocky Mountains. Hardy and fine.

All Hardy Perennials, unless otherwise noted, are $30 \mathrm{cts}$. each; $\$ 2.50$ per $10 ; \$ 20.00$ per 100 .

\section{HERBACEOUS PEONIES.}

The Mount Desert Nurseries for many years have made a specialty of the Herbaceous Peonies. Their collection of these to-day comprises the best varieties obtainable, and none other. The numerous named varieties introduced from year to year have been carefully tested by them, and those alone which have shown some marked superiority have been retained. These and the best of the older kinds are what we offer, forms - old and new - which actual trial has proved the most desirable in their respective classes.

\section{Double.}

Alba sulphurea. White petals, lemon centre, a strong grower, pleasantly scented, tall, early.

Armandine Mechin. Pure mauve, large, fairly compact flowers, fragrant, tall, mid-season.

Charles Verdier. Reddish-violet, large flower and fine shape, medium height, late.

Claire Dubois. A large fine flower; delicate rose color, deeper on the underside.

Couronne d'Or. White suffused with yellow, large and late.

Delachi. Plum-violet, good, late.

Duchesse de Nemours. White petals, pale sulphur-yellow, fragrant, tall. A grand variety.

Duchess of Orleans. A beautiful rich pink, deeper in the centre, free blooming, fragrant, tall, mid-season.

Duchess of Teck. An early-flowering dwarf variety, rich rosy color shading to white at the edges, large and fine. 
Duke of Clarence. One of the best mid-season varieties of medium height, with outside petals pale pink and the shorter ones a delicate cream color. Very fragrant.

Duke of Wellington. White, large, well-formed flowers, vigorous grower, free flowering, fragrant, late.

Eden. Rosy-magenta with violet-rose tips, very full, free bloomer; fragrant, dwarf, mid-season.

Eugene Verdier. Guard petals beautifully flushed violet-rose shading to a rosy-white near the edges; flowers very large and of a peculiar charm, broad foliage, tall, early.

Festiva maxima. A magnificent white flower with carmine centre. A great favorite.

Fushimi. A peculiar and distinct flower, violet-rose suffused with yellow.

Jeromus. Violet-rose, full flower and fine form, tall, fragrant, late. Superb variety.

Jules Calot. Pure mauve, with violet-rose tips; medium height; mid-season.

Kelway's Queen. Rosy-magenta shading to solferino-rose at tips, medium height, strong growing, mid-season.

Lady Beresford. A very beautiful flower of solferino-red, strong growing, mid-season.

Mme. Auguste Peltereau. White suffused with pale rose; dark, broad foliage; fragrant, tall, late.

Mme. Chaumy. Reddish-violet; full, loose flower; medium height; mid-season.

Mme. Lebon. Lilac-purple with solferino tips, large, round and full flowers, splendid dark green foliage, tall, late.

Marie Lemoine. A large and effective white flower, a strong and vigorous grower and a free bloomer, fragrant, medium height, very late.

Mrs. Asquith. Solferino-red with violet-rose tips, very full flower, mid-season.

Mrs. Chamberlain. Rosy-flesh color, tall, very late.

Messionier. Guard petals deep purple-red; centre, deep crimson.

\section{Semi-double.}

Bridesmaid. Faintly tinted pale rose fading to white; guard petals with white base; very delicate and fine, medium height, early.

Jessieu. Large, deep-crimson petals loosely arranged; a fine variety, fragrant, tall, mid-summer.

Mount Kebo. White, suffused with rich rose fading to white, fragrant, very tall.

Pemetic. Reddish, with vinous mauve edges, medium height, late. An excellent variety.

Hyberbolus. Large, rosy petals shading to a pale pink at the tips; base white, tall, early.

Lady Wimbourne. Violet-rose shading to white at the base and edges, petals short and round, fragrant, tall, long-blooming season.

Oniverie. Rich violet, tall, one of the earliest.

Stanley. Deep purple; conspicuous golden stamens, tall, early.

Price on any of the Peonies listed $\$ 1.00$ each; $\$ 7.50$ per 10 . Price on clumps according to size selected.

\section{PHLOX.}

The Hardy Phloxes, like the Irises and Peonies, are plants in which the Mount Desert Nurseries have specialized for years. No plants give greater return in beauty and superb effect. Ranging from the low Moss Pinks that spread carpets of bright bloom in spring over the rockery or border-bank to the tall, late-flowering forms derived from Phlox paniculata and its type, their season covers nearly the whole flowering period, ending in a great display. They are completely hardy but the stronger-growing species need rich soil and moisture for successful flowering, and all are better for some light covering - such as nature gives of leaves or withered grass - in winter.

Antonin Mercie. Grayish-lavender, or violet-mauve, with white centre; flowers very large.

40 cts. each; $\$ 3.50$ per $10 ; \$ 30$ per 100 .

Beacon. Brilliant, rich red; three to four feet tall.

Cigale. A pure rose color, and one of the best. This is one of the dwarf varieties, seldom exceeding eighteen inches.

All Hardy Perennials, unless otherwise noted, are 30 cts. each; $\$ 2.50$ per $10 ; \$ 20.00$ per 100 . 
Crepuscule. Crimson centre changing to rich lilac, with white edge. Two to three feet.

Eugene Danzanvilliers. Lilac-blue with white centre. Two to three feet.

Elizabeth Campbell. Bright salmon-pink with white eye; centre very slightly marked with crimson.

50 cts. each; $\$ 4.00$ per $10 ; \$ 35$ per 100 .

Europa. White with crimson centre, three feet tall, mid-season blooming.

Faust. Large white flowers with small pink eye. Two to two and one-half feet tall.

Frau Ant. Buchner. Large, pure white. One of the best white-flowered varieties.

George B. Dorr. Pure mauve, with small white centre; large and branching panicles; foliage excellent.

Gruppenkonigin. A beautiful variety, with large trusses of pale rose flowers.

Iris. One of the purple varieties, less dark than Le Mahdi. Three feet tall.

James Bennett. Tall salmon-pink with carmine eye, midsummer.

Josephine Gerbeaux. Tall, white with large crimson eye. One of the old favorites.

Le Mahdi. Dark purple. Should be included in every collection; is very effective in a mass.

Louise Abbema. A dwarf; pure white and very large flowers.

Mme. Paul Deutrie. Bright rose with white eye, flowers very large and borne in long trusses.

Miss Lingard. An early-flowering variety, pure white with rosy centre. A profuse bloomer and fine garden plant.

Pantheon. A salmon-rose, late-blooming variety of medium height.

R. P. Struthers. A deep rosy-pink with red centre which blooms profusely.

Rynstrom. Immense trusses with large individual florets of bright carminerose.

Sylphide. Pure white, of medium height, profuse bloomer.

W. C. Egan. Color, as a whole, a pleasing shade of soft pink. 40 cts. each; $\$ 3.50$ per $10 ; \$ 30$ per 100 .

\section{* Alpine Varieties.}

amoena. Very distinct, with deep rose-colored flowers.

divaricata Laphami. Improved form of type, with blue flowers.

subulata. Moss Pink. Low, creeping form with evergreen foliage and masses of pink flowers in June and July, carpeting the ground.

subulata alba. Pure white.

\section{PHYSOSTEGIA. False Dragon's Head.}

virginiana. Pale purple flowers in terminal racemes on stalks three to four feet high, commencing to bloom the early part of August.

virginiana alba. Pure white, very effective in a mass.

\section{PLATYCODON. Chinese Bellflower.}

A handsome perennial allied to the Campanulas but with more open flowers. grandiflorum. Large blue flowers on slender stems, two feet in height. grandiflorum album. White, with delicate blue shadings.

\section{POLEMONIUM. Jacob's Ladder.}

Useful border plants thriving best in a partially shaded position; deep green, pinnately divided foliage, and spikes of blue flowers.

Richardsoni. Sky-blue flowers with golden anthers. June and July.

\section{POLYGONATUM. Solomon's Seal.}

Few plants possess more grace or give greater pleasure than the oldfashioned Solomon's Seal. It belongs to the Lily family, a near cousin to the Lily-of-the-Valley, and has deep green, pinnate leaves springing from a long, arching stalk, with white, bell-shaped flowers pendent from their axils. A partly shaded situation suits it best, and once established should be left undisturbed. 


\section{PYRETHRUM.}

roseum. A fine plant of the Daisy type from the Caucasian region, which has yielded under cultivation many varieties, single and double, of which the following are among the best. They thrive in any good garden soil if given a sunny and well-drained position, blooming in early July, and are valuable for decorative use as cut flowers.

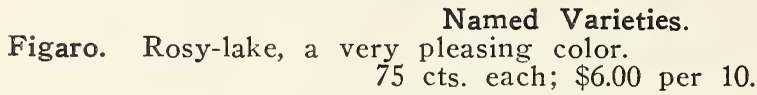

Lord Roseberry. Brilliant carmine-scarlet.

75 cts. each; $\$ 6.00$ per 10.

Queen Mary. Large lavender-pink flowers.

75 cts. each; $\$ 6.00$ per 10.

Yvonne Cayeux. Primrose, shading to buff.

75 cts. each; $\$ 6.00$ per 10.

Hybrid, single mixed.

A beautiful collection of single flowering hybrids.

30 cts. each; $\$ 2.50$ per $10 ; \$ 20$ per 100 .

RUDBECKIA. Cone Flower.

The Rudbeckias are handsome North American Composites bearing in profusion showy, generally yellow, flower-heads with conspicuous central cone. laciniata plena. Golden Glow. A very popular double-flowered variety, six feet tall, planted generally in masses.

Newmani. Yellow flowers with black centres, blooming in profusion from July to October. Three feet.

speciosa. A dwarf variety, fine for bedding, with deep yellow flowers with black centre.

subtomentosa. A free-flowering and late-blooming species, with golden rays and black centres.

\section{SAPONARIA.}

*ocymoides. A beautiful trailing rock plant with prostrate stems and bright pink flowers completely hiding its leaves and branches in the early summer.

officinalis plena. Bouncing Bet. Light pink flowers, July and August; excellent for naturalizing.

\section{*SAXIFRAGA. Rockfoil.}

The Saxifrage family contains many of the finest rock and alpine plants, plants essential to the rock garden be it large or small. The freedom with which its species grow in all cool climates and their beauty of flower and foliage make them perhaps the most valuable group of alpine plants which we possess.

cordifolia. A Siberian plant with large heart-shaped leaves, massive foliage, and heads of reddish flowers in spring.

cordifolia purpurea. A richly colored form of the above.

McNabiana. Rosettes of silvery foliage and spikes of pure white flowers, each branching stem carrying hundreds of blooms.

palmata. White flowers and dark green, basal foliage.

pyramidalis. Silvery rosettes of foliage and tall spikes of white flowers spotted with red. This and McNabiana are the handsomest varieties in our collection.

\section{SEDUM. Stonecrop.}

The Stonecrops are typical rock plants, thriving in the driest situations. They form an interesting and attractive group.

\section{*Dwarf Species.}

acre. Very dwarf, useful as a ground cover; yellow.

album. Very close growing with a profusion of white blossoms.

anacampseros. Low growing, with erect flower stems and dull purple flowers. anglicum. Glaucous foliage and sheets of white flowers.

brevifolium. Thick, fleshy leaves and a quantity of rosy-pink flowers.

ibericum. Throughout the summer the foliage of this takes on a reddish hue; the flowers are pink.

All Hardy Perennials, unless otherwise noted, are $30 \mathrm{cts}$. each; $\$ 2.50$ per 10; $\$ 20.00$ per 100 . 
kamtschaticum. Fleshy leaves and numerous heads of yellow flowers. oppositifolium. A low-growing species with yellowish-white flowers. rupestre. One of the most distinct. Dark green foliage.

stoloniferum coccineum. An attractive trailing variety with numerous reddishpink flowers.

Erect Species.

aizoon. Grayish-green leaves and pale yellow flowers.

spectabile. A strong-growing form with large, fleshy, glaucous leaves and immense, flat-topped heads of pink flowers on stems one and one-half feet tall.

spectabile Brilliant. Richly colored form of the above.

*SEMPERVIVUM.

Succulent rock and alpine plants, forming rosette-like tufts of fleshy leaves and thriving in dry and stony situations where scarcely any other plant could grow.

arachnoideum. Small rosettes threaded with a white, cobweb-like down.

globiferum. Medium-sized rosettes, the tips of which are tinted reddish-brown.

Greeni. A strong-growing variety with large rosettes of green leaves.

tectorum. House Leek. The best-known and most popular form. Leaves green, with a distinct reddish-brown tip, in large rosettes, three to four inches in diameter.

tectorum rubrum. Differing from the above only in a deeper shading on the tips of the leaves.

\section{SENECIO.}

clivorum. A handsome border plant from China, of recent introduction, with large, heart-shaped leaves and tall, much-branched, showy heads of orangeyellow flowers. A bold waterside plant of easy culture.

Veitchianus. Bright yellow flowers, borne on tall stems four to five feet high, rising well above the foliage.

Wilsonianus. This variety also produces rich golden-yellow flowers on tall stems, four to five feet high. August flowering.

\section{SIDALCEA. Indian Mallow.}

Rosy Queen. An erect-growing plant, two to three feet high, bearing bright rosy flowers during June and July.

\section{SPIRAEA. Meadow Sweet.}

The Herbaceous Spiraeas or Meadow Sweets are moisture-loving plants of exceptional grace and beauty, and constitute an important group of garden plants, valuable also for the waterside or wild garden planting on moist land.

aruncus. Goat's Beard. A vigorous perennial, three to five feet tall, fine in foliage and habit as in flower, its flowers being freely produced in summer in large, gracefully drooping plumes.

filipendula. Dwarf-growing plants with attractive fern-like foliage and heads of creamy, white flowers. June and July.

filipendula plena. A double form, with pure white flowers. One of the finest of the dwarf-growing varieties.

gigantea rosea. A tall form with light pink flowers.

kamtschatica. A strong-growing species with handsome foliage and large clusters of white flowers on stems fully six feet high.

lobata. (Ulmaria rubra.) Queen of the Prairies. One of the best of the Herbaceous. Spiraeas, growing from two to three feet high with deep rosy flowers in large terminal cymes.

pentapetala plena. A plant about three feet tall with double white flowers in July.

purpurea (palmata). A species growing from two to three feet high with crimson flowers in large panicles.

purpurea alba. Similar to the above but having white flowers.

\section{STACHYS.}

betonica, var. superba. A plant twelve to eighteen inches high with spikes of rosy-purple flowers.

lanata. Foliage silver-white, flowers purple.

rosea grandiflora. A low-growing plant, useful alike for rockery or garden. Spikes of rosy-pink flowers.

All Hardy Perennials, unless otherwise noted, are 30 cts. each; $\$ 2.50$ per 10; \$20.00 per 100 . 
STATICE. Sea Lavender.

Plants of the Leadwort or Plumbago family, growing natively along the seashore. Most of the species bear broadly branching flower-stems covered with myriads of small flowers.

latifolia. Flowers lilac-blue, borne in large panicles from July to September.

THALICTRUM. Meadow Rue.

These are plants of meadow-land and moist wayside, valuable for their light, graceful foliage and feathery bloom.

adiantifolium. A fine variety with fern-like foliage and feathery white flowers, blooming in July.

aquilegifolium. A tall and handsome species with fine foliage and feathery heads of white flowers. Five feet.

aquilegifolium, var. atropurpureum. Pale purple-flowering form of the above. glaucum. Strong-growing species with handsome glaucous foliage and creamywhite flowers. Five feet.

THERMOPSIS.

caroliniana. A tall perennial with long terminal spikes of attractive yellow, lupin-like flowers through June and July.

mollis. A lower-growing form with branching stems and deep yellow flowers.

*THYMUS. Thyme.

Low, creeping plants, spreading quickly into dense cushions.

citriodorus. Lemon-scented Thyme, one of the best of the genus, with tiny pink flowers.

lanuginosus. Soft gray leaves and rosy flowers.

serpyllum. Green leaves and tiny bright rose flowers. This is the Wild Thyme of England.

TROLLIUS. Globe Flower.

Fine perennials of the Ranunculus or Buttercup family with handsome dark green foliage and flowers like golden globes, terminal on the stems; among the best of all spring-flowering plants.

asiaticus. Bright orange-colored flowers of medium size.

35 cts. each; $\$ 3.00$ per $10 ; \$ 25$ per 100 .

caucasicus. Orange Globe. A handsome variety with large orange flowers on tall stems.

35 cts. each; $\$ 3.00$ per $10 ; \$ 25$ per 100 .

europea. Bright lemon-yellow flowers produced in greater abundance and lasting for a longer period than those of anv other species.

35 cts. each; $\$ 3.00$ per $10 ; \$ 25$ per 100 .

hybridus Goldquelle. Large globe-like flowers of orange-yellow, on long stems.

35 cts. each; $\$ 3.00$ per $10 ; \$ 25$ per 100 .

hybridus Thomas S. Ware. A very fine form. Flowers orange-yellow, of large size on tall stems.

35 cts. each; $\$ 3.00$ per $10 ; \$ 25$ per 100 .

japonica excelsa. Handsome semi-double flowers, golden-orange.

35 cts. each; $\$ 3.00$ per $10 ; \$ 25$ per 100 .

*TUNICA.

saxifraga. A dwarf, tufted rock plant, with little rosy flowers in profusion upon wiry stems.

VALERIANA. Valerian.

cfficinalis. A very hardy, strong-growing plant with small, aromatic flowers in clusters. It has fragrant, showy foliage and is a plant well-suited to the border or wild garden.

\section{* VERONICA. Speedwell.}

incana. Gray silvery foliage in striking contrast to rich blue flowers. One foot. longifolia. A vigorous species, with lilac-blue flowers, growing about two feet in height.

longifolia subsessilis. Long branching stems of rich blue flowers and dark green foliage. Two to three feet.

repens. White flowers in quantity on prostrate stems.

All Hardy Perennials, unless otherwise noted, are 30 cts. each; $\$ 2.50$ per 10; $\$ 20.00$ per 100 . 
Royal Blue. A creeping, dwarf variety with crowded spikes of rich blue flowers.

rupestris. A trailing species, excellent for carpeting rockeries or covering bare spots. Beautiful blue flowers.

spicata. Spikes about eighteen inches long of violet-blue flowers. Thrives best in open exposure.

\section{* VIOLA CORNUTA. Horned Pansy.}

A mountain pansy with violet-like flowers; a valuable plant for bedding in the Herbaceous Border or groups in the Rock Garden, forming splendid masses of deep or pale blue color, or of pure white, and blooming through spring and summer.

cornuta. Abundant pale blue flowers from spring to frost.

cornuta alba. A white-flowered form.

cornuta atropurpurea. A deep blue form.

\section{YUCCA.}

filamentosa. One of the finest of hardy plants, with ivory-white bell-flowers pendent on erect branching stalks rising from a mass of dark green, swordshaped foliage. It is the only member of an extensive genus that is hardy in the north, and it is one of its best. 


\section{Deciduous Trees}

Trees - plants that build up a woody stem to carry their leaves into the sun - adapt themselves less readily than the Herbaceous Plants to climatic change, and the number in general of those not native to a region which may be grown in it successfully is few. The experience of the last hundred years in eastern North America, a period filled with the experimental introduction of species from other lands, has been to show not how many but how few may be grown with permanent success. The foundation for permanent plantation should be the native, regional trees. In its native hardwoods - the deciduous trees-eastern North America has a rich heritage in which Maine fully shares.

The finest deciduous trees in our region are: The Canoe and Yellow Birches, here growing at their best and splendid trees; the White Ash; the Red Oak; the American Beech; the Red Maple. The Elm does not grow natively upon our coast, or well. The Sugar Maple grows freely on it but less abundantly and to lesser size than in the interior. The Norway Maple, one of the most popular of nursery trees, more rapidly grown and readily transplanted than the native species, is valuable chiefly in its younger stages, when its spreading habit and abundant foliage make rapid greenery. The White Willow, a western Asiatic species that seems indifferent to climatic change within the north temperate zone, grows like a native here and is a valuable landscape tree. The Balm of Gilead Poplar, a native of the northern forest, is in northern regions a wonderfully vigorous and strong-growing tree, valuable in many ways in landscape planting.

Among the beautiful flowering and fruiting trees, the Thorn and the Mountain Ash are native to this region and elements of conspicuous beauty in its landscape. The Flowering Crab and the Apple are not native but flourish exceedingly under right conditions. The importance of the Apple as a fruit-bearer has obscured its value to the landscape planter; it is one of the most beautiful of flowering trees, long-lived, robust and picturesque.

ACER platanoides. Norway Maple.

$8-10 \mathrm{ft}$

Each 10

$10-12 \mathrm{ft}$

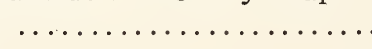

$\$ 2.00 \$ 17.50$

Specimens $\$ 3.00$ to $\$ 10.00$ each

platanoides, var. Schwedleri. Purple-leaved Norway Maple.

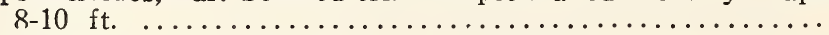

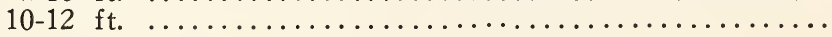

rubrum. Red Maple.

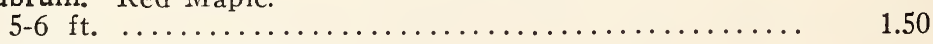

saccharum. Sugar Maple.

$8-10 \mathrm{ft}$

\section{Specimens $\$ 3.00$ to $\$ 10.00$ each}

spicatum. Mountain Maple.

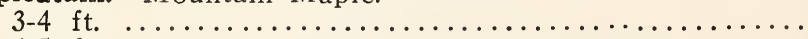

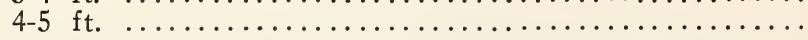

BETULA alba, var. laciniata. Cut-leaved European Birch.

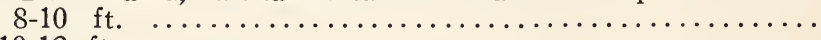

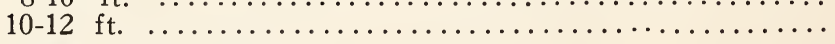

lutea. Yellow Birch.

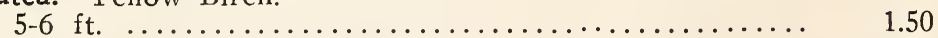

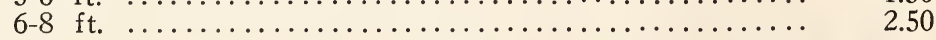

NoтE: - Specially selected plants will be charged according to their individual value. 
papyrifera. Canoe Birch.

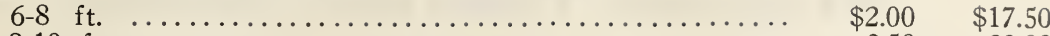

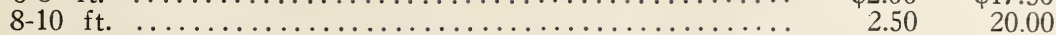

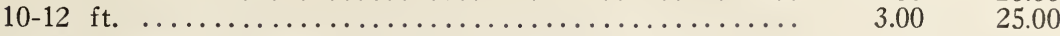

CRATAEGUS Arnoldiana. Arnold Thorn.

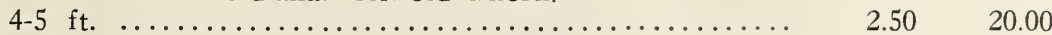

$5-6$ ft. ............................................... $3.50 \quad 30.00$

crus-galli. Cockspur Thorn.

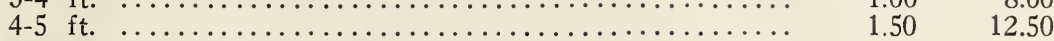

macracantha. Scarlet Thorn.

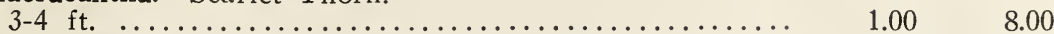

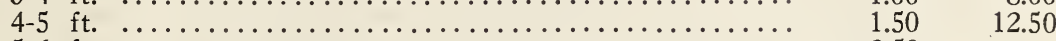

$5-6 \mathrm{ft} . \ldots \ldots \ldots \ldots \ldots \ldots \ldots \ldots \ldots \ldots \ldots \ldots \ldots \ldots \ldots \ldots \ldots \ldots \ldots \ldots, 2.50$

prunifolia. Plurn-leaved Thorn.

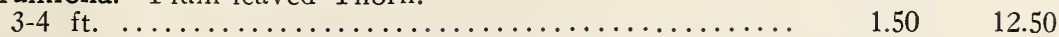

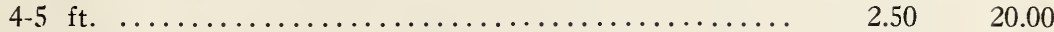

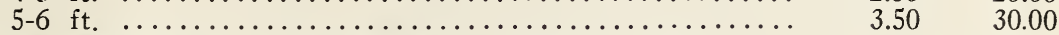

FAGUS americana (F. ferruginea). American Beech.

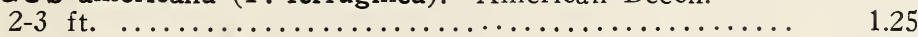

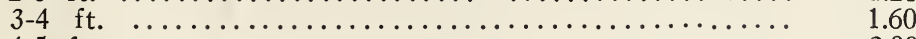

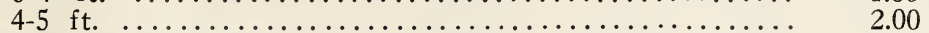

sylvatica, var. Riversi. Purple Beech.

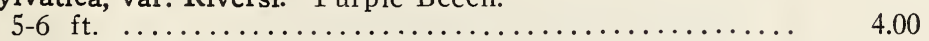

FRAXINUS americana. White Ash.

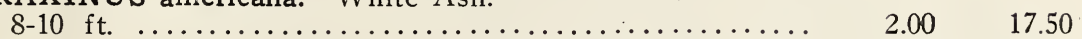

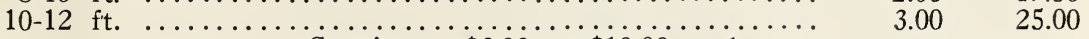

LARIX decidua. European Larch.

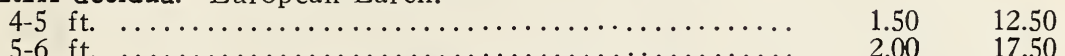

Specimens $\$ 2.00$ to $\$ 7.00$ each

POPULUS balsamifera. Balm of Gilead Poplar.

6-8 ft. ............................................ $1.50 \quad 12.50$

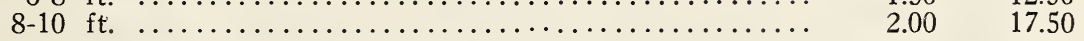

deltoides, var. monolifera. Carolina Poplar. $\quad 1.50 \quad 12.50$

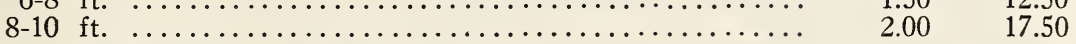

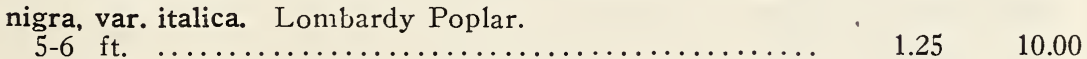

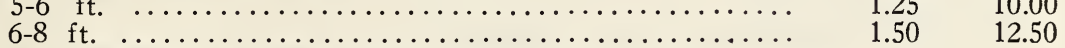

PYRUS angustifolia rosea plena. Double-flowering pink Crab.

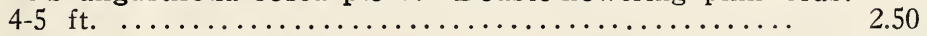

Bechtel's. Bechtel's Crab.

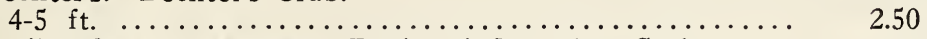

floribunda atropurpurea. Dark-red flowering Crab.

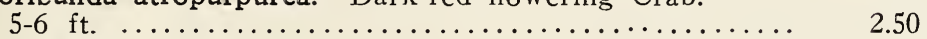

SALIX alba. White Willow.

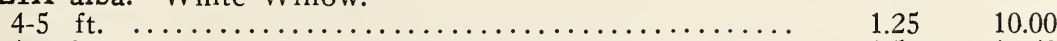

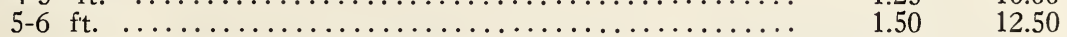

pentandra. Laurel-leaved Willow.

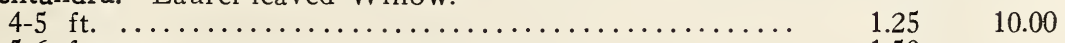

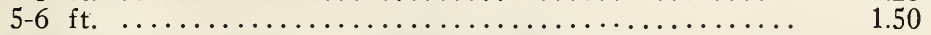

rosmarinifolia. Rosemary-leaved Willow.

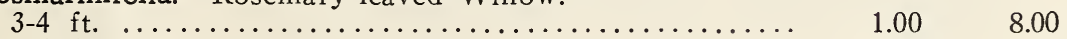

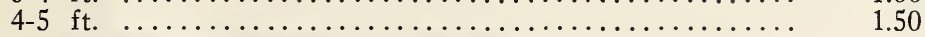

vitellina, var. Britzensis. Red-barked Willow.

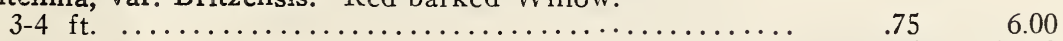

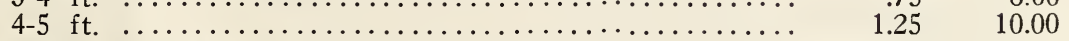

SORBUS americana. American Mountain Ash.
$4-5 \mathrm{ft} . \ldots \ldots \ldots \ldots \ldots \ldots \ldots \ldots \ldots \ldots \ldots \ldots \ldots \ldots \ldots \ldots \ldots \ldots \ldots \ldots$

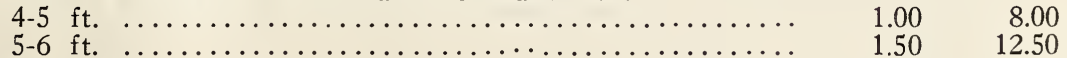

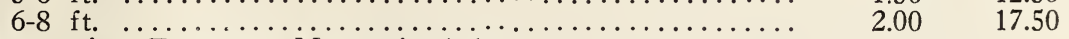

aucuparia. European Mountain Ash.

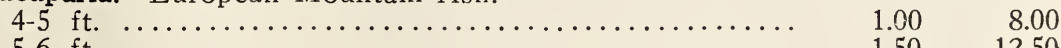

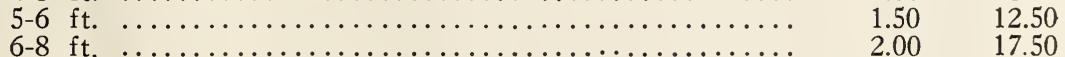

Nоте: - Specially selected plants will be charged according to their individual value. 


\section{Evergreen Trees and Shrubs}

Maine is a region of fine native evergreens. The White Pine gives the State its name of Pine Tree State, and there is no finer tree. The Hemlock is its companion, coming next in size and stateliness, while both - as all our native evergreens - make beautiful young trees. After these comes the White Spruce, an exclusively northern tree of rapid growth with splendid glaucous foliage.

The Red Pine when young is the most beautiful tree of its type in eastern North America; losing its lower limbs as it grows older, it loses in beauty as it gains in trunk but is a noble forest tree, growing best in dry and rocky situations.

The Norway Spruce, a tree of sombre hue with long, drooping limbs, does not possess the sturdy habit or rich color of the native species, nor does it grow in America to full age and size, but it is valuable for its rapid growth, its wide adaptability, and the ease with which it can be transplanted. It makes an excellent hedge.

The Arbor Vitae, known locally as the Cedar, one of the most widely grown of landscape plants, flourishes in our region, where it is native. Growing in pyramidal fashion, dense-foliaged to the ground, it makes a splendid feature on the lawn or warm-toned back-ground to the garden, and it makes also one of the best of hedges.

The Austrian Pine is a robust and hardy tree, valuable for its dense habit and handsome foliage. It makes an admirable screen and splendid wind-break, but it does not grow in the American climate to its native European size or age.

ABIES concolor. Western Fir.

Each $\quad 10$

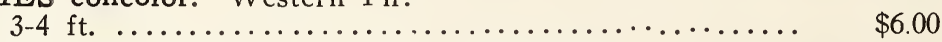

*ARCTOSTAPHYLOS Uva-ursi. Bearberry.

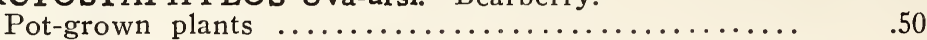

*EMPETRUM nigrum. Crowberry.

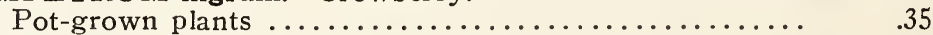

JUNIPERUS communis. Ground Juniper.

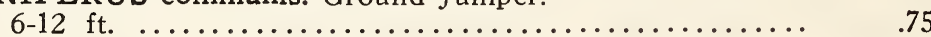

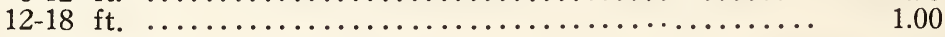

*horizontalis. Prostrate Juniper.

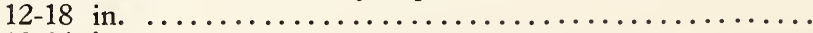

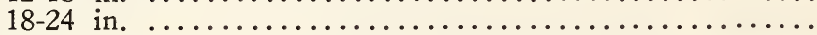

PICEA excelsa. Norway Spruce.

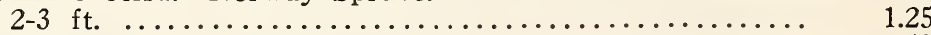

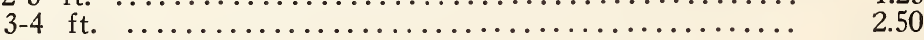

$1.00 \quad 8.00$

$1.50 \quad 12.50$

$1.25 \quad 10.00$

glauca.
$4-5 \mathrm{ft}$.

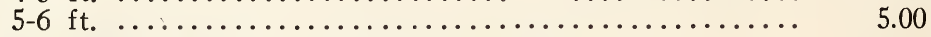

pungens, var. glauca. Colorado Blue Spruce.

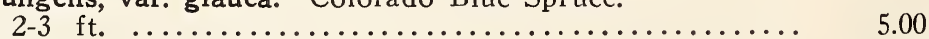

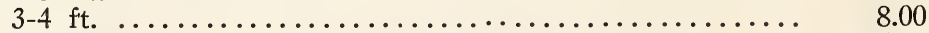

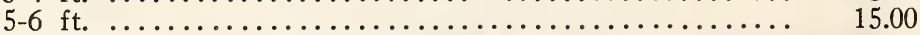

PINUS austriaca. Austrian Pine.

Specimens from $\$ 15$ to $\$ 50$ each.

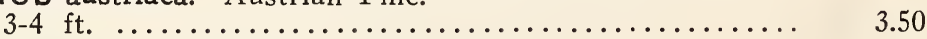

30.00

Banksiana (P. divaricata). Gray Pine.

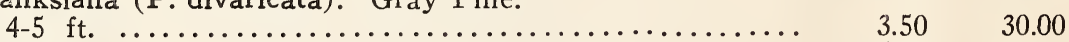

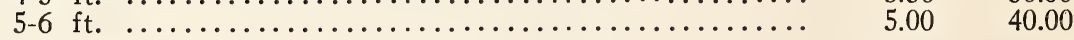

montana, var. mugho. Dwarf Mountain Pine.

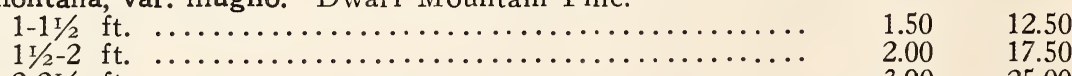

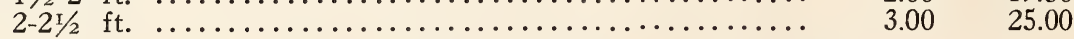

Note: - Specially selected plants will be charged according to their individual value. 
resinosa. Red Pine.

Each $\quad 10$

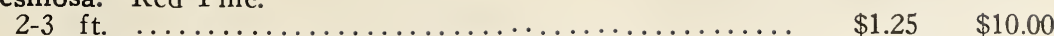

3-4 ft. .................................. $2.00 \quad 17.50$

strobus. White Pine.

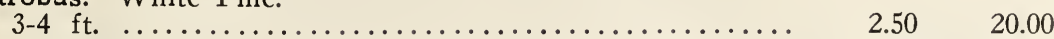

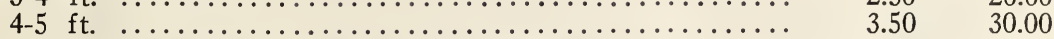

THUYA occidentalis. American Arbor Vitae.

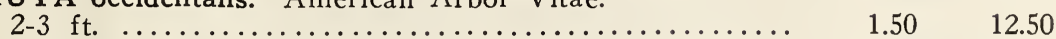

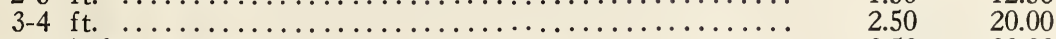

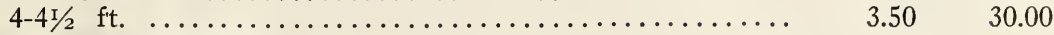

occidentalis globosa.

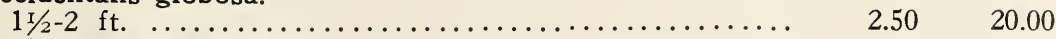

occidentalis pyramidalis.

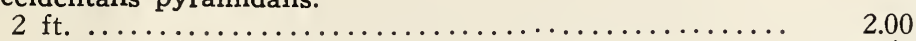

3 ft. $\ldots \ldots \ldots \ldots \ldots \ldots \ldots \ldots \ldots \ldots \ldots \ldots \ldots \ldots \ldots \ldots \ldots \ldots \ldots \ldots, \quad 3.50$

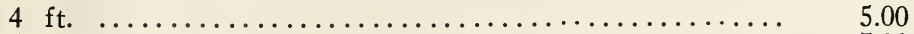

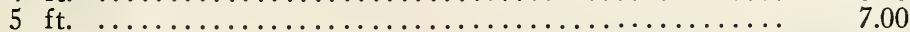

6 ft. $\ldots \ldots \ldots \ldots \ldots \ldots \ldots \ldots \ldots \ldots \ldots \ldots \ldots \ldots \ldots \ldots \ldots \ldots \ldots \ldots \ldots, \quad 8.50$

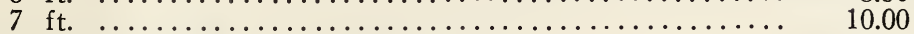

TSUGA canadensis. American Hemlock.

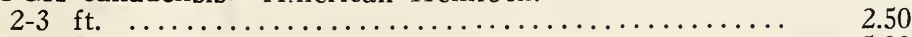

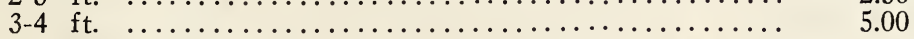

\section{Deciduous Shrubs}

The deciduous-leaved flowering shrubs do wonderfully in our climate and may be grown in a wide range. The flowering of some the Lilacs, the Bush Honeysuckles, the Syringas or Mock Oranges, the Viburnums and a number more - is a sight worth coming far to see. Of these the many garden forms and wide variety make advice - to suit the individual need - better than description, not attempted in the following list. This applies also to the Cultivated Roses; to the Apples, wherein Maine stands pre-eminent in certain finer kinds; and to the Berry Fruits, to whose fine quality and flavor, as to those of the finer summer vegetables, the Island climate lends itself remarkably.

AMELANCHIER botryapium. Shad Bush.

3-4 $\mathrm{ft}$.
BERBERIS Thunbergi. Japanese Barberry.

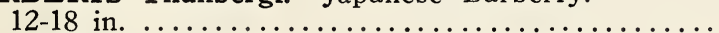

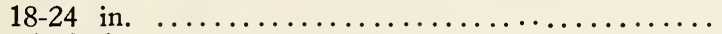

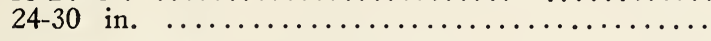

Thunbergi Dwarf. Box Barberry.

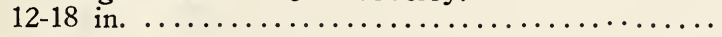

vulgaris. European Barberry.

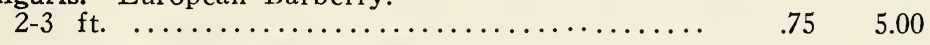

vulgaris, var. purpurea. Purple-leaved Barberry.

$2-3 \mathrm{ft}$. .......................................... Carolina Allspice.

CALYCANTHUS florida. Carolina Allspice.

Each $\quad 10 \quad 100$

$\$ 1.00 \$ 8.00$

$\begin{array}{ccc}.40 & 3.50 & \$ 30.00 \\ .60 & 5.00 & 40.00 \\ .75 & 6.00 & 50.00 \\ .60 & 5.00 & 40.00 \\ .75 & 5.00 & \\ .75 & 5.00 & \\ 1.00 & 8.00 & \\ 1.00 & 8.00 & \end{array}$

CORNUS alba, var. sibirica. Siberian. Red-twigged

$3-4 \mathrm{ft} . \ldots . . . .$.
RUS alba, var.

3-4 $\mathrm{ft}$. Dogwood.

amomum. Silky Dogwood.

$1.00 \quad 7.50$

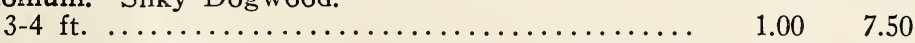

mas. Cornelian Cherry.

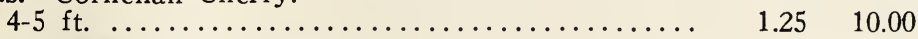

paniculata. Panicled Dogwood.

$1.00 \quad 7.50$

$3-4 \mathrm{ft}$.
tolonifera. Red Osier Dogwood.

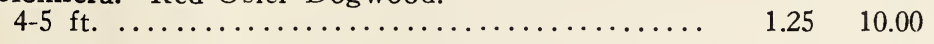

Note:- Specially selccted plants will be charged according to their individual value. 
COTONEASTER dielsiana.

Each $\quad 10$

$3-3 \mathrm{r} / 2 \mathrm{ft}$.

$\$ 2.50 \$ 20.00$

$3 \mathrm{r} / 2-4 \mathrm{ft}$

Specimens $\$ 3.00$ to $\$ 5.00$ each

divaricata.

$3.00 \quad 25.00$

$3-3 \mathrm{t} / 2 \mathrm{ft}$

$3 \mathrm{I} / 2-4 \mathrm{ft}$

horizontalis.

$2.50-20.00$

$1 \mathrm{I} / 2-2 \mathrm{ft}$.

$3.00 \quad 25.00$

$2-2 \mathrm{I} / 2 \mathrm{ft}$

$\begin{array}{ll}.75 & 15.00\end{array}$

$2.50 \quad 20.00$

Moupinensis.

4-5 $\mathrm{ft}$.

Specimens $\$ 3.00$ to $\$ 5.00$ each.

numullaria.

$3.00 \quad 25.00$

$2 \mathrm{I} / 2-3 \mathrm{ft}$

3-4 ft.

Specimens $\$ 3.00$ to $\$ 5.00$ each.

CYDONIA japonica. Japanese Quince.

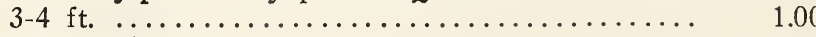

$1.00 \quad 8.00$

$1.50 \quad 12.50$

japonica hybrids.

3-4 ft.

1.50

7.50

DEUTZIA Lemoinei.

2-3 ft.

12.50

3-4 $\mathrm{ft}$

1.00

6.00

DIERVILLA desbosi. Pink Weigela.

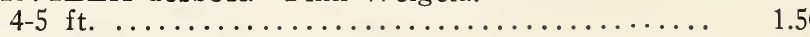

floribunda. Crimson Weigela.

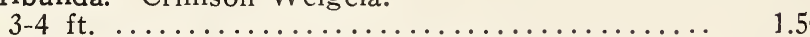

$1.50 \quad 12.50$

florida. Weigela rosea. Rose Weigela.

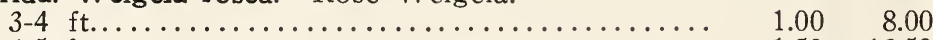

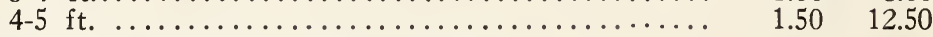

florida, var. candida. White Weigela.

$1.00 \quad 8.00$

florida, var. Kosteriana variegata. Koster's variegated Weigela.

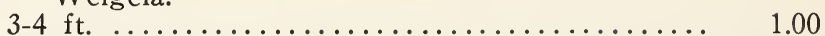

hybrida Groenwegeni. A beautiful pink-flowered hybrid.

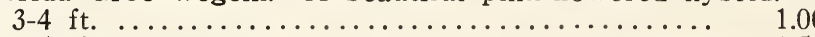

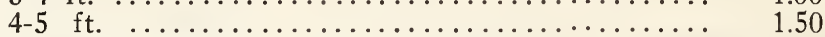

800

12.50

hybrida Eva Rathke. Carmine Weigela.

3-4 ft. ............................... 1.00

8.00

EUONYMUS alatus. Winged Burning-bush.

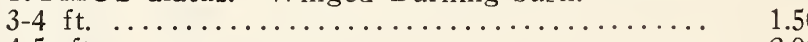

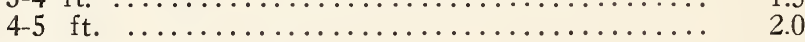

Sieboldianus. Spindle Tree.

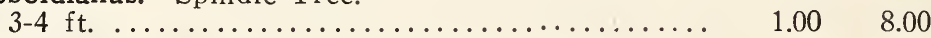

$4-5$ ft. ............................. $1.50 \quad 12.50$

FORSYTHIA intermedia. Golden Bell.

3-4 ft. ................................. $1.00 \quad 8.00$

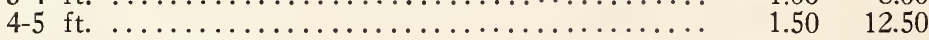

suspensa, var. Fortunei.

3-4 ft. .................................. $1.00 \quad 8.00$

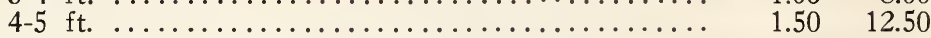

HYDRANGEA arborescens grandiflora alba.

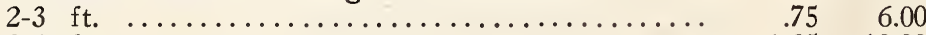

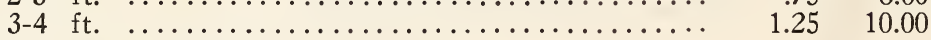

paniculata grandiflora.
$2-3 \mathrm{ft}$
$3-4 \mathrm{ft} . \ldots \ldots \ldots \ldots \ldots \ldots \ldots \ldots \ldots \ldots \ldots \ldots \ldots \ldots \ldots \ldots \ldots \ldots$

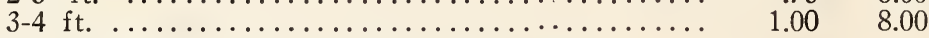

ILEX verticillata. Black Alder. Winter Berry.

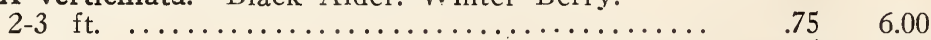

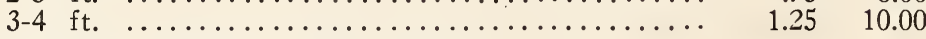

LABURNUM vulgare. Golden Chain. $\ldots \ldots \ldots \ldots . . . \ldots$

$4-5 \mathrm{ft}$.
$5-6 \ldots \ldots \ldots \ldots \ldots \ldots \ldots \ldots \ldots \ldots \ldots \ldots \ldots \ldots \ldots \ldots \ldots \ldots \ldots \ldots \ldots \ldots \ldots \ldots \ldots$

Note:- Specially selected plants will be charged according to their individual value. 
LIGUSTRUM ibota. Japanese Privet.

Each $\quad 10 \quad 100$

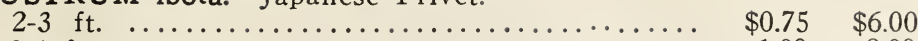

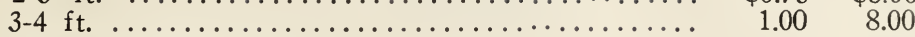

vulgare. Common Privet.

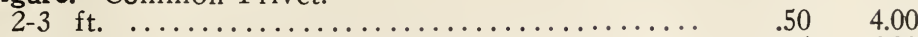

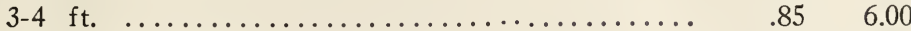

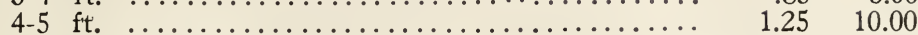

LONICERA bella incarnata. Bush Honeysuckle. Pink.

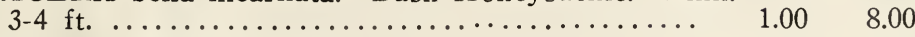

Maacki podocarpa. White.

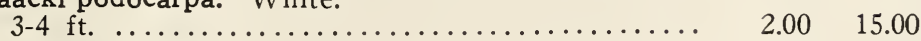

Morrowi. White.

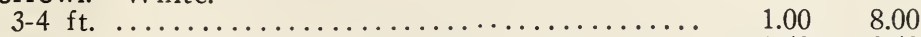

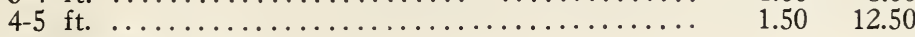

Ruprechtiana. White.
$3-4 \mathrm{ft} . \ldots \ldots \ldots \ldots \ldots \ldots \ldots \ldots \ldots \ldots \ldots \ldots \ldots \ldots \ldots \ldots \ldots$

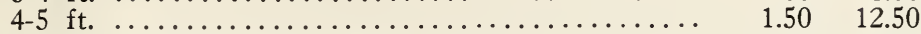

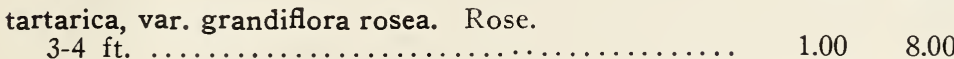

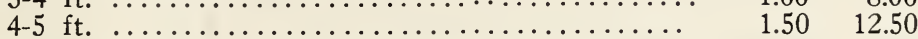

MALUS Sargentae. Sargent's Flowering Crab.

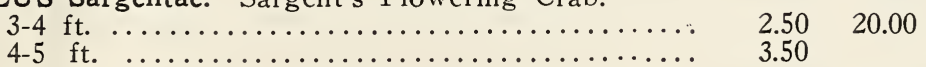

MYRICA cerifera. Candleberry.

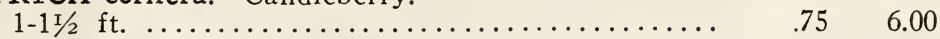

PHILADELPHUS coronarius. Syringa. Mock Orange.

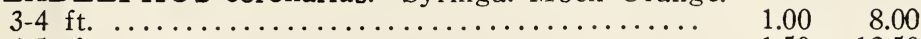

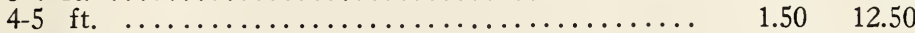

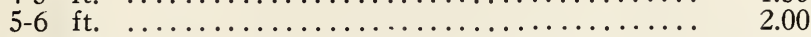

grandiflorus.

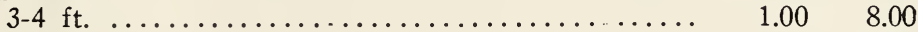

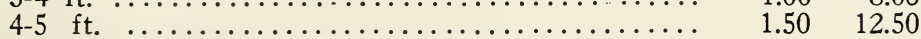

Lemoinei Avalanche.

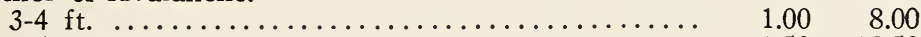

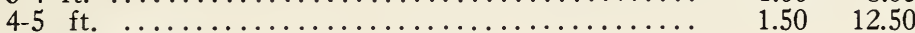

PHYSOCARPUS opulifolius. Ninebark.

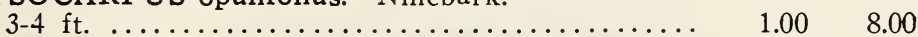

opulifolius aureus. Golden Ninebark.

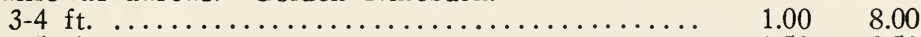

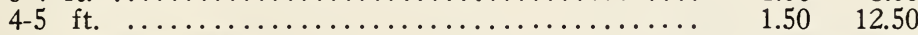

PRUNUS glandulosa.

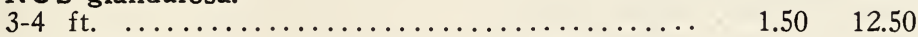

Maximowiczi.

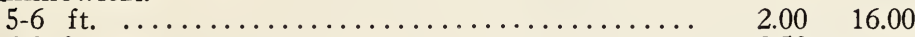

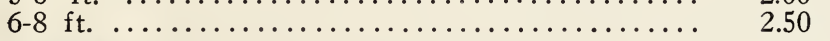

subhirtella.

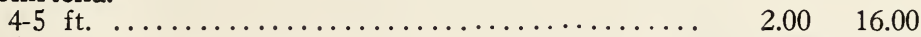

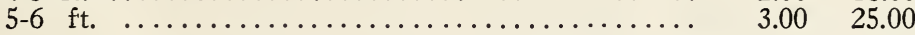

ROSES. In separate section, following list of shrubs.

SPIRAEA arborea.

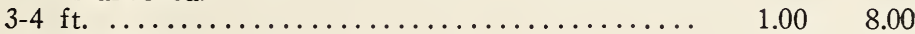

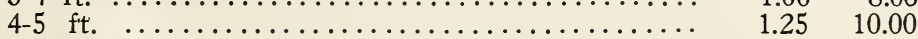

arborea glabra.

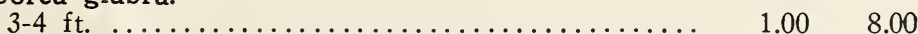

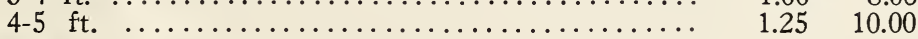

arguta.

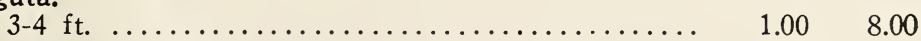

bracteata.

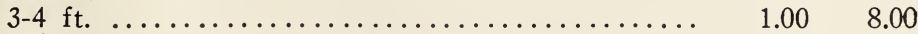

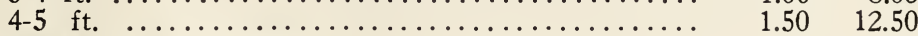

bumalda, var. A. Waterer.

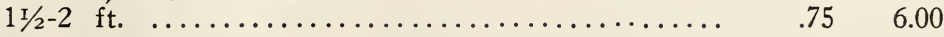

Menzesi Triumpha.

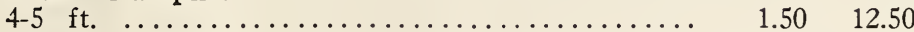

Nore: - Specially selected plants will be charged according to their individual value. 
prunifolia plena.

Each 10

2-3 ft.

$\$ 0.75$

$\$ 6.00$

sorbifolia.

$2-3 \mathrm{ft}$.

6.00

Thunbergi.

1.00

8.00

Van Houttei.

3-4 $\mathrm{ft}$.

$1.00 \quad 8.00$

4-5 ft.

$1.25 \quad 10.00$

Veitchi.

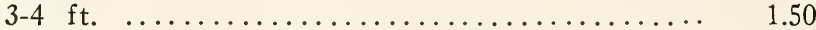

$1.50 \quad 12.50$

4-5 f

$2.00 \quad 17.50$

SYMPHORICARPUS racemosus. Snowberry.

3-4 ft.

$1.00 \quad 8.00$

vulgaris.

3-4 $\mathrm{ft}$

$1.00 \quad 8.00$

SYRINGA japonica. Japanese Lilac.

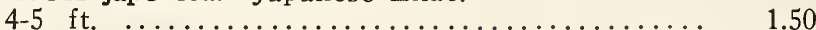

2.00

pekinensis. Chinese Lilac.

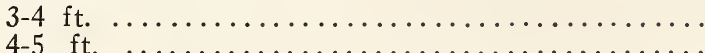

$1.00 \quad 8.00$

$1.50 \quad 12.50$

persica. Persian Lilac.

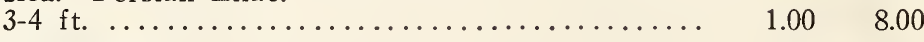

rothomagensis.

$3-4 \mathrm{ft}$

$1.00 \quad 8.00$

villosa.

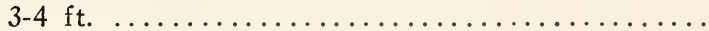

$1.00 \quad 8.00$

$1.50 \quad 12.50$

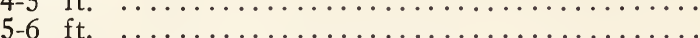

$2.00 \quad 17.50$

vulgaris. Common Lilac.

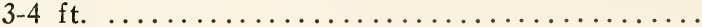

$1.00 \quad 8.00$

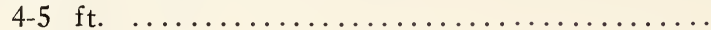

$1.50 \quad 12.50$

vulgaris, var. alba. White Lilac.

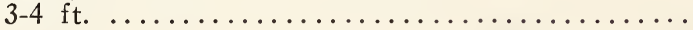

4-5 ft.

$1.00 \quad 8.00$

(Named Varieties of Lilacs.)

Charles X. Large purple flowers.

Congo. Very dark purple.

Madame Lemoine. Double white.

Mme. Casimir Perier. Double white.

Marie Legraye. Single white.

Michael Buchner. Double pale lilac.

Souv. de Ludwig Spaeth. Single dark purple.

Any of the above $2-3 \mathrm{ft}$.

3-4 ft.

$1.25 \quad 10.00$

$1.75 \quad 15.00$

VIBURNUM cassinoides. Withe Rod.

2-3 ft.

$3-4 \mathrm{ft}$

$.75 \quad 6.00$

$1.25 \quad 10.00$

dentatum. Arrow Wood.

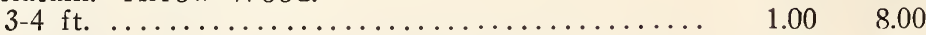

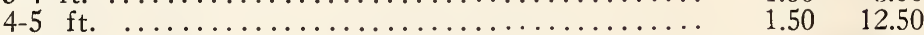

lantana. Wayfaring Tree.

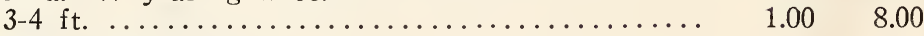

lentago. Sheep Berry.

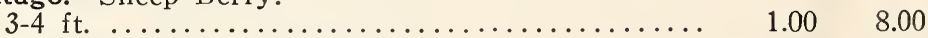

opulus. High Bush Cranberry.

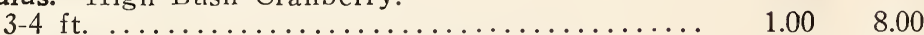

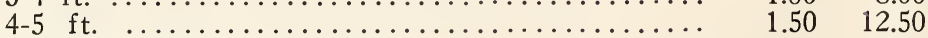

opulus, var. sterilis. Snowball.

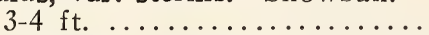

$1.00 \quad 8.00$

tomentosum. Japanese Snowball.

$2-3 \mathrm{ft}$.

$\begin{array}{ll}.75 & 6.00\end{array}$

3-4 ft.

$1.25 \quad 10.00$

Note: - Specially selected plants will be charged according to their individual value. 


\section{Roses}

ROSA carolina. Wild Swamp Rose.

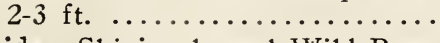

Each 10

100

lucida. Shining-leaved Wild Rose.

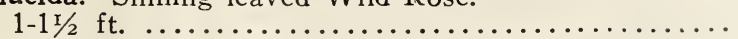

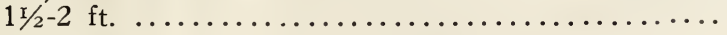

multiflora.

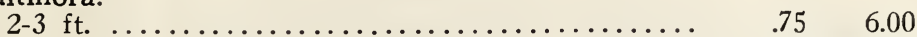

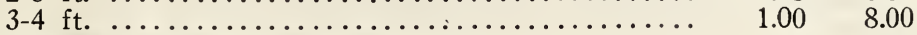

rubiginosa. Sweet Brier. Eglantine.

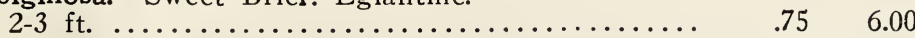

rubrifolia. Red-leaved Rose.

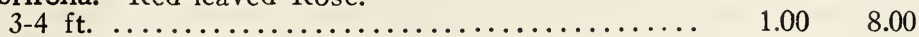

rugosa. Japanese Rose.

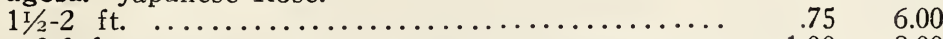

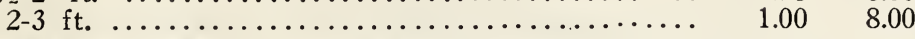

rugosa, var. alba. White-flowered Japanese Rose.

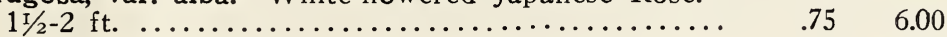

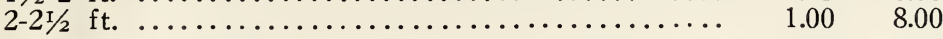

ROSA rugosa hybrids, in the following varieties:

Belle Poitevine, Blanc de Coubert, Conrad F. Meyer,

Nova Zembla and Sir Thomas Lipton. ...........

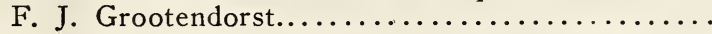

$1.00 \quad 8.00$

$2.00 \quad 17.50$

\section{HYBRID PERPETUAL ROSES.}

Clio. Flesh color, shaded in the centre to rosy-pink. Vigorous grower and free bloomer.

Hugh Dickson. Brilliant crimson, shaded scarlet. A grand rose and a very strong grower.

Margaret Dickson. White with pale flesh centre; very large petals, handsome foliage.

Mrs. John Laing. Soft rosy-pink. Very large and of excellent form.

Paul Neyron. Deep rosy-pink. Immense flowers with fine foliage and good growth.

Ulrich Brunner. Cherry-red; of immense size, full form, and most effective. One of the first to flower and lasts well throughout the season. Vigorous grower.

\section{HYBRID TEA ROSES.}

Betty. Gold overlaid with yellow.

Caroline Testout. Bright satin rose with brighter centre. Large full flower and free bloomer. Very sweet scented.

Etoile de France. Velvety crimson, fine long bud; free flowering and strong growing.

Frau Kar1 Druschki. Undoubtedly the finest pure white rose in existence. Long buds with shell-shaped petals opening to very large flowers. A continuous and free bloomer.

General McArthur. Brilliant, glowing crimson-scarlet; a much-admired rose.

George Arends. A pink form of the Frau Karl Druschki. Large, full, and deliciously scented.

Gruss an Teplitz. Scarlet, shading to velvety crimson. A very fragrant and profuse blooming variety.

Killarney. A sparkling, brilliant pink. Flowers are large and buds long and pointed. A strong and vigorous plant.

Killarney White.

Ophelia. Light salmon-pink color with yellow at base of petals; long, stiff stems. Red Radiance. A dazzling crimson-scarlet variety which is a continuous bloomer.

Price: Any of the above $\$ 1.00$ each; $\$ 9.00$ per 10 . 


\section{BABY RAMBLERS.}

Baby Dorothy. A pink 'baby' rambler which blooms in masses like the climbing Dorothy Perkins. Strong and free blooming.

Echo. A soft tender rose color.

Ellen Poulson. Dark brilliant pink, large and sweetly scented; very free flowering.

Mrs. Cutbush. A rose-pink variety.

Orleans. Brilliant geranium-red, with large, white centres. Excellent color combination. Free flowering.

Prices: $\$ 0.75$ each; $\$ 6.00$ per 10 .

\section{HARDY CLIMBING AND TRAILING VARIETIES.}

American Pillar. A single-flowering variety of a lovely shade of pink, with a clear white eye.

Crimson Rambler. Bright crimson flowers borne in immense clusters.

Dorothy Perkins. Countless clusters of double pink flowers of a most beautiful shade.

Dorothy Perkins. White. A white form of the above.

Dr. Van Fleet. Light pink, gradually deepening to a rich shell-pink in the centre. Large blossoms borne on long stems.

Excelsa. Brilliant scarlet-crimson flowers of the same type as the Dorothy Perkins.

Hiawatha. A single-flowering variety of great beauty. Deep crimson shading to white at the base. Strong vigorous grower.

Lucille. Double blooms of a delicate flesh-pink tinged with rosy-salmon, produced in large clusters.

Paradise. A single variety of a beautiful shade of pink, white centres.

setigera. Large single flowers of deep rose color. Very ornamental.

Tausendschon. This climbing rose stands at the head of those best suited to our climate. Its flowers, which are of a beautiful shade of soft pink, are about two inches across and are borne in clusters.

Trier. A lovely creamy double white with yellow anthers. Bushy in habit. Wichuraiana. A single white of trailing habit.

Note: The above are two-year-old roses, grown in the open one year and one year in pots. They are sold from five and six inch pots.

Price $\$ 1.00$ each.

\section{Vines and Climbers}

Vines, rightly used, are of the highest value in architectural and landscape planting. The best to use in the Mount Desert region are: Actinidia arguta, a strong-growing Japanese vine which climbs to great heights by graceful twining stems; Celastrus scandens, the Bitter Sweet, a vigorous twining climber with handsome foliage which bears in early fall clusters of bright yellow berries; Aristolochia sipho, the Dutchman's Pipe, with broad green leaves completely draping walls or fences and bearing quaint, pipe-like blooms; the Virginia Creeper, Ampelopsis quinquefolia, with foliage changing beautifully in fall; and the Hardy Grapes, Vitis coignetiae and Vitis riparia.

The Climbing Honeysuckles, the Clematises and the Climbing Roses belong rather among the flowering plants than to leafy drapery but where there is trellis, wall, arbor or fence on which to grow them they are supremely beautiful.

ACTINIDIA arguta.

Each $\quad 10 \quad 100$

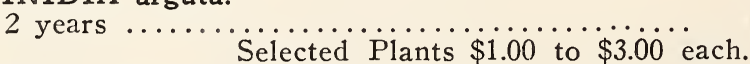

AKEBIA quinata.

3-year plants 
AMPELOPSIS quinquefolia. Virginia Creeper.

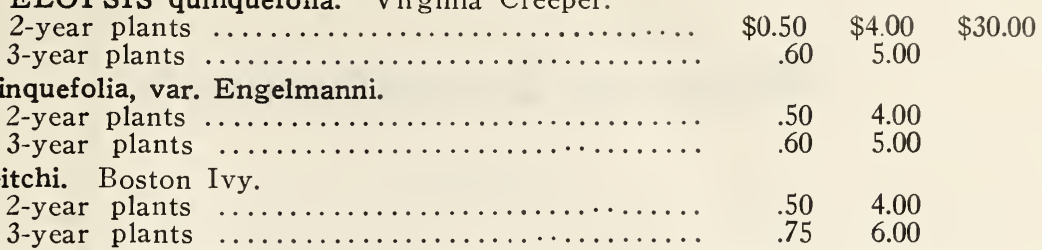

ARISTOLOCHIA sipho. Dutchman's Pipe.

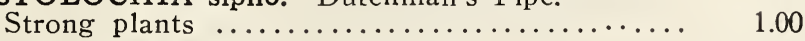

CELASTRUS scandens. Bitter Sweet.

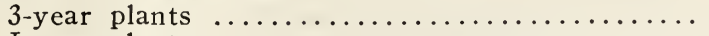

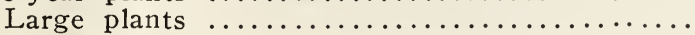

Specimens

$\begin{array}{lll}.50 & 4.00 \quad 30.00\end{array}$

$\begin{array}{lll}1.00 & 8.00 & 60.00\end{array}$

$\begin{array}{lll}1.50 & 12.00 & 100.00\end{array}$

CLEMATIS paniculata. Japanese White Clematis.

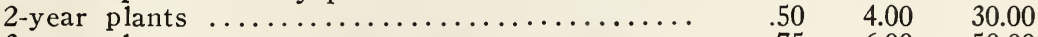

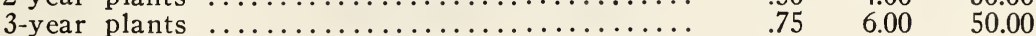

virginiana. Native White Clematis.

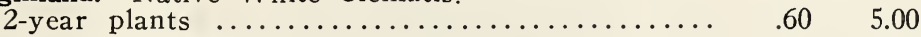

Large flowering hybrids:

Jackmani. Purple ....................... $1.00 \quad 8.00$

Henryi. White. ....................... $1.00 \quad 8.00$

LONICERA belgica. Dutch Honeysuckle. Monthly blooming.

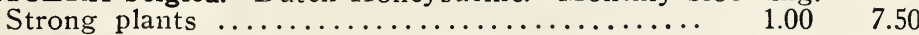

sempervirens. Trumpet Honeysuckle. Scarlet Honeysuckle.

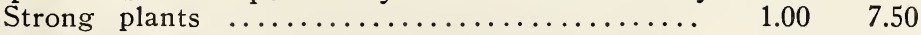

VITIS coignetiae. Hardy Grape.

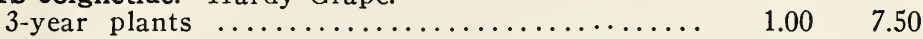

riparia. Frost Grape.
3 -year plants $\ldots \ldots \ldots \ldots \ldots \ldots \ldots \ldots \ldots \ldots \ldots \ldots$
$1.0 \ldots \ldots \ldots$

\section{Fruit Department}

APPLES.

Summer:

Early Harvest, Red Astrachan, Yellow Transparent, and Sweet Bough.

Autumn:

Fameuse, Gravenstein.

Winter:

Baldwin, Bellflower, Delicious, King, McIntosh Red, Northern Spy, and Crab:

Wolf River.

Hyslop.

Price: 2-year No. $1-\$ 1.50$ each; $\$ 12.50$ per 10 . 3 and 4 year $-\$ 2.50$ each; $\$ 20.00$ per 10. Larger trees priced according to size.

Bartlett, Seckel, and Sheldân.

\section{PEARS.}

Price: 2-year No. $1-\$ 1.50$ each; $\$ 12.50$ per 10 . Larger trees priced according to size.

PLUMS.

Abundance, Burbank, and Red June.

Price: 2 -year No. $1-\$ 1.50$ each; $\$ 12.50$ per 10 .

Agawam and Snyder.

BLACKBERRIES.

Price: $\$ 1.25$ per $10 ; \$ 8.00$ per 100 .

Cuthbert - Red Variety.

RASPBERRIES.

Golden Queen -- Yellow.

Price: $\$ 1.25$ per $10 ; \$ 8.00$ per 100 .

For August planting only.

STRAWBERRIES.

Write for price. 


\section{Notice to Correspondents}

\section{SHIPPING SEASON.}

OUR shipping season opens in the spring, about the 15 th of April, closing in early June according to the season. In the fall it extends from the end of August to the beginning of December.

\section{FALL PLANTING.}

With a few exceptions, fall planting of the herbaceous plants is as successful as spring, and many of the early-flowering plants, storing their food over winter, should be planted in the fall, when possible, in preference to the spring.

Woody plants need greater care in fall than spring transplanting, but may be moved successfully.

\section{SELECTED STOCK.}

Stock selected by customers at the Nurseries, or specially selected stock ordered by mail or otherwise, will be charged at advanced rates according to the value of the stock selected.

\section{QUANTITY.}

Five of one kind and size will be furnished at the ten rate.

\section{PACKING.}

Packing will be done in the most careful manner for shipment to any part of the world. We have made a special study of good packing, and our most distant shipments have rarely failed to reach their destination in the best condition. The packing of Trees and Shrubs will be charged for at actual cost. Herbaceous plants of all kinds will be packed without charge.

\section{DELIVERY.}

All goods are delivered f. o. b. Bar Harbor. Local orders will be delivered free to any portion of the village.

\section{SHIPPING.}

We can ship either by the Maine Central Railroad or by steamers connecting directly with steamers to New York and Boston, or by American Railway Express. Customers are requested to state the mode of shipment; otherwise we shall forward according to our best judgment. After delivery to the forwarding agent all goods are at the risk of the purchaser. 


\section{INSPECTION.}

A certificate of inspection will be sent with each shipment where required.

\section{ERRORS.}

Customers will confer a great favor if they will notify us promptly of any error that may have been made in filling their orders, to enable us immediately to correct the error.

\section{CLAIMS.}

Claims, to receive consideration, must be made immediately upon receipt of goods.

\section{NON-WARRANTY.}

While we use the utmost care to have our nursery stock, plants, bulbs and seeds true to name, and will replace any that may prove untrue, no sale by us carries a warranty, express or implied, as to the description, quality, productiveness, or other character of any nursery stock, bulbs, plants or seeds which we send out, nor will we be in any way responsible for the crop; and for any error we shall not be held liable for more than the purchase price. Every purchase from us is made on these terms.

\section{THE MOUNT DESERT NURSERIES}

Bar Harbor, Maine 



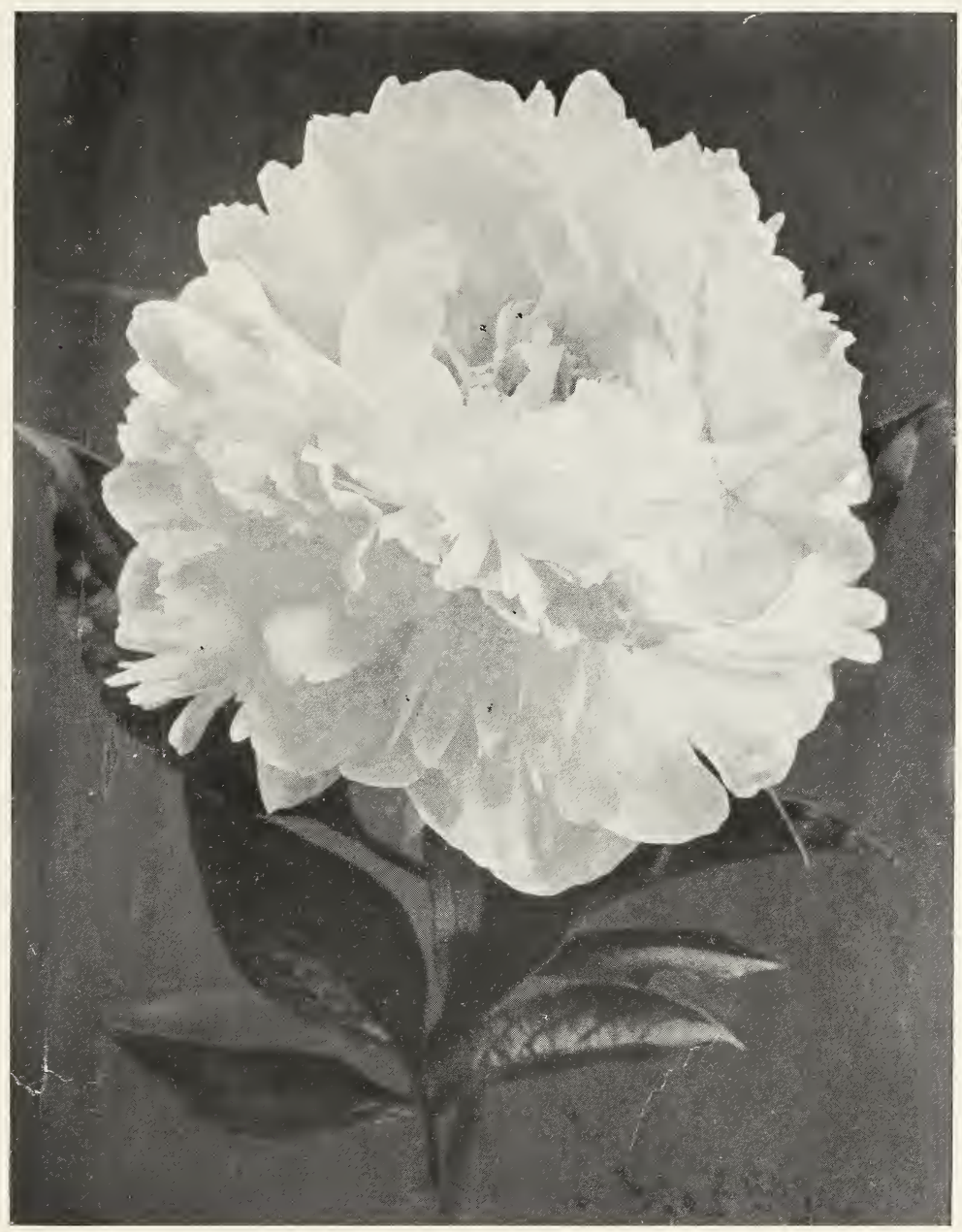

A SPLENDID TYPE OF PURE-WHITE DOUBLE PÆONY THE MOUNT DESERT NURSERIES, BAR HARBOR, MAINE 


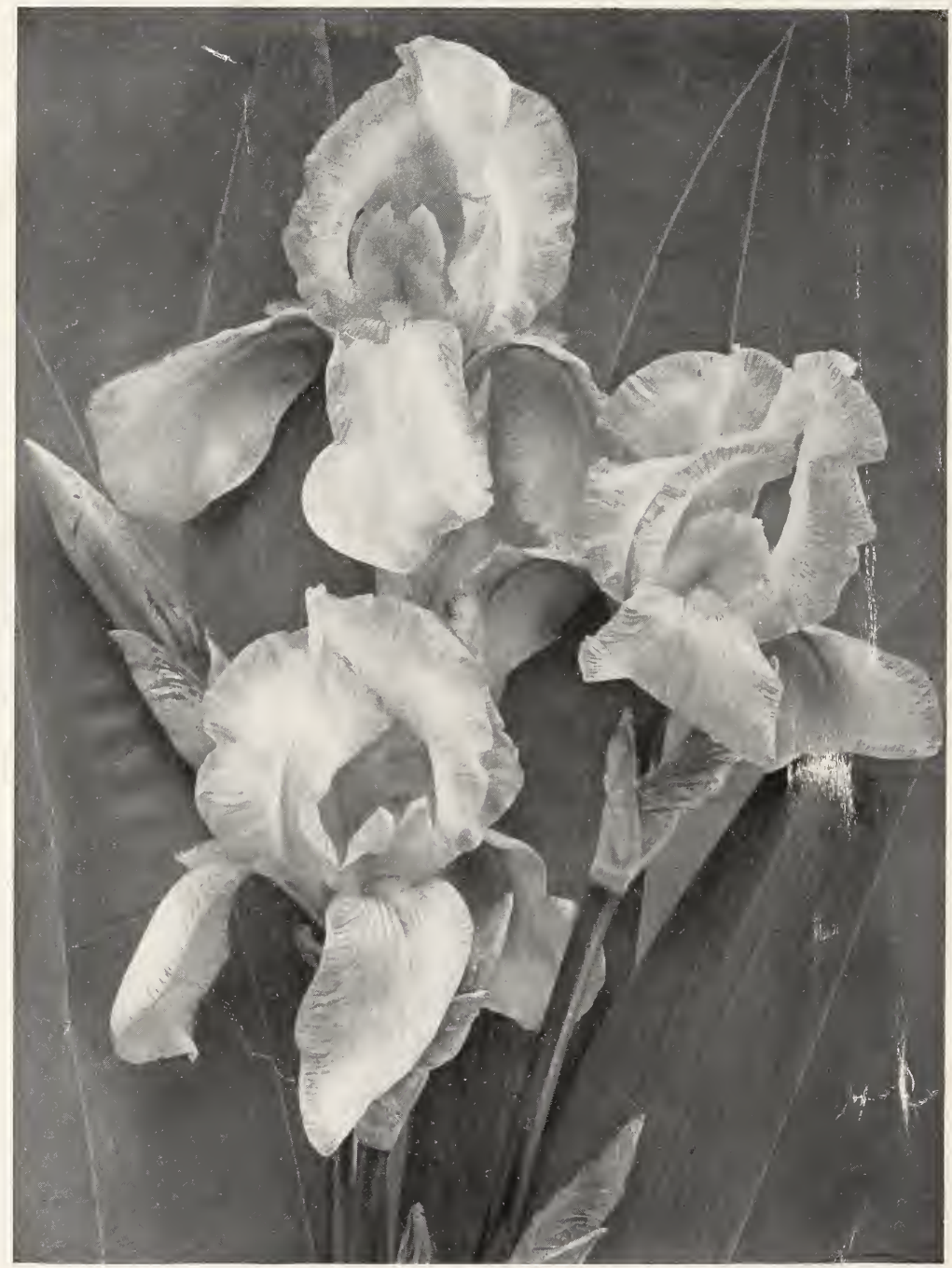

IRIS HYBRIDS

Of the beautiful and fragrant Florentine Iris type THE MOUNT DESERT NURSERIES, BAR HARBOR, MAINE 